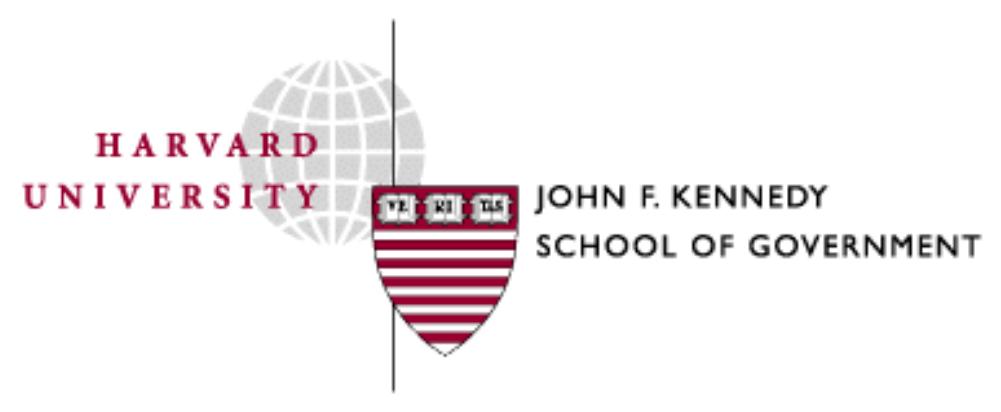

Faculty Research Working Papers Series

\title{
E-Rulemaking: Information Technology and the Regulatory Process Cary Coglianese
}

January 2004

RWP04-002 belongs to the author(s). Papers may be downloaded for personal use only. 


\section{E-Rulemaking: \\ Information Technology and the Regulatory Process}

\section{Cary Coglianese*}

Introduction.................................................. 1

I. The Emergence of E-Rulemaking.............................. 4

A. Key Characteristics of Rulemaking...................... 5

B. The Rise of E-Rulemaking............................ 9

C. E-Rulemaking's Potential.............................. 12

II. E-Rulemaking: Prospects and Challenges......................... 16

A. Goals for E-Rulemaking............................... 16

B. Technology Design Choices............................ 22

C. Institutional Challenges and Constraints..................... 25

III. Directions for Future Research............................... 27

A. A Policy Analytic Research Framework................... 27

B. Functional Aspects of Rulemaking....................... 30

C. Research Directions in E-Rulemaking..................... 31

Conclusion................................................... 35

Appendix A: Washington, D.C. Workshop Participants............... 37

Appendix B: Cambridge Workshop Participants.................... 40

\footnotetext{
* Irvine Visiting Professor of Law, Stanford Law School; Associate Professor of Public Policy and Chair of the Regulatory Policy Program, John F. Kennedy School of Government, Harvard University. The Digital Government Research Program at the National Science Foundation made this project possible under award number EIA-0226053, and the Program's staff -- Larry Brandt, Valerie Gregg, and Sue Stendebach - offered helpful guidance and encouragement at every point along the way. This article draws on the many valuable contributions offered by the researchers and practitioners who participated in e-rulemaking workshops organized by the Regulatory Policy Program, as well as the insights shared by workshop executive committee members and the helpful comments on earlier drafts provided by Steve Balla, Bob Carlitz, Claire Cardie, Ed Hovy, Roger Hurwitz, Neil Kerwin, Kincho Law, Liz Liddy, Beth Novack, Rick Otis, Jarrett Perlow, Ed Schwalenberg, Peter Shane, Stuart Shulman, Geoff Steele, Sue Stendebach, Chris Weare, and Gio Wiederhold. In addition, Bernard Cahill, Amy Christopher, Kate Dodson, Eric Lockwood, Jennifer Nash, Todd Olmstead, and Camiliakumari Wankaner, all of the Center for Business and Government, contributed in many ways to organizing the workshops. Allan Friedman, Todd Olmstead, Sabine Schaffer, Özlem Uzuner, and Sarah Wilford took helpful notes of the discussions, and Sam Walsh provided excellent research assistance in the final preparation of this article. This article summarizes and synthesizes the perspectives that emerged at the Regulatory Policy Program's workshops, so the views expressed here do not necessarily reflect those of the author, the Regulatory Policy Program, the Kennedy School of Government, Harvard University, or the National Science Foundation. Moreover, while this article summarizes workshop discussion, it does not necessarily represent the views of all the participants nor should it be construed to represent any consensus statement or shared set of findings or recommendations.
} 


\title{
E-Rulemaking: Information Technology and the Regulatory Process
}

\author{
Cary Coglianese
}

\section{Introduction}

Over one hundred federal regulatory agencies and subagencies collectively issue more than 4,500 new regulations every year. ${ }^{1}$ These rules govern virtually every major aspect of contemporary life. Efficient and productive markets depend on appropriate regulation of key sectors such as banking, securities, communications, energy, and transportation. Government regulation also helps secure vital public benefits by delivering food safety, environmental quality, and investor and consumer protection. Taken together, the federal government's health, safety, and environmental regulations yield up to an estimated $\$ 250$ billion to $\$ 1$ trillion in benefits to the public each year. ${ }^{2}$

Crafting government regulations imposes significant information demands on regulatory agencies, from completing scientific, engineering, and economic analyses to processing and responding to extensive public comments. Information is vital for understanding complex problems, identifying the need for regulation, and analyzing alternative regulatory designs. Electronic rulemaking, or e-rulemaking, offers the potential to overcome some of the informational challenges associated with developing regulations. E-rulemaking refers to the use of digital technologies in the development and implementation of regulations. The use of these technologies may help streamline and improve regulatory management, such as by helping agency staff retrieve and analyze vast quantities of information from diverse sources. By taking better advantage of advances in digital technologies, agencies might also be able to increase the public's access to and involvement in rulemaking. ${ }^{3}$

\footnotetext{
1 John D. Graham, Remarks Prepared for Delivery to the National Economists Club, Library of Congress (March 7, 2002) available at http://www.whitehouse.gov/omb/legislative/testimony/graham030702.html.

2 OMB, "Making Sense of Regulation: 2001 Report to Congress on the Costs and Benefits of Regulations and Unfunded Mandates on State, Local and Tribal Entities," (2001) available at http://www.whitehouse.gov/omb/inforeg/costbenefitreport.pdf. See also OMB, "Stimulating Smarter Regulation: 2002 Report to Congress on the Costs and Benefits of Regulations and Unfunded Mandates on State, Local and Tribal Entities," available at http://www.whitehouse.gov/omb/inforeg/2002_report_to_ congress.pdf (estimating that annual costs for regulations promulgated between April 1, 1995 and September 30, 2001 are between $\$ 50$ billion and $\$ 53$ billion and annual benefits are between $\$ 48$ billion and $\$ 102$ billion); OMB "Informing Regulatory Decisions: 2003 Report to Congress on the Costs and Benefits of Federal Regulations and Unfunded Mandates on State, Local and Tribal Entities," available at http://www.whitehouse.gov/omb/inforeg/2003_cost-ben_final_rpt.pdf (reviewing 107 major regulations promulgated between 1992 and 2002 and estimating annual benefits from $\$ 146$ billion to $\$ 230$ billion and annual costs from $\$ 36$ billion to $\$ 42$ billion) [hereinafter OMB, Informing Regulatory Decisions]. See also Robert W. Hahn \& Erin Layburn, Tracking the Value of Regulation, 26 REG. (Fall 2003), at 16-21.

3 Barbara H. Brandon \& Robert D. Carlitz, Online Rulemaking and Other Tools for Strengthening Our Civic Infrastructure, 54 Admin. L. Rev. 1421, 1422 (2003); Stephen Zavestoski \& Stuart W. Shulman, The Internet and Environmental Decision Making: An Introduction, 15 ORG. \& ENV'T 323 (2002); Stephen
} 
In recent years, agencies have constructed websites containing rulemaking documents and have allowed the public to submit electronic comments on proposed rules, thus making it easier for members of the public to learn about and participate in the rulemaking process. ${ }^{4}$ The Clinton Administration's National Performance Review encouraged government agencies to explore new applications of information technology, ${ }^{5}$ and e-rulemaking has formed a major part of the Bush Administration's e-government initiative. ${ }^{6}$ In 2003, the Bush Administration launched a web portal designed to facilitate electronic filing of public comments on proposed regulations (www.regulations.gov), an accomplishment that represented the first phase of the Administration's e-rulemaking strategy. ${ }^{7}$ In addition, the Office of Management and Budget has recently incorporated erulemaking into its own regulatory review process, making all of its studies and decisions accessible via the Internet. ${ }^{8}$ Efforts such as these will almost certainly persist beyond the current administration, if for no reason other than the enactment of the E-Government Act of 2002, which calls for federal agencies to use information technologies in adjudicatory and rulemaking proceedings. ${ }^{9}$

In order to ensure that the growing interest in e-rulemaking leads to effective and meaningful innovations, computer technologies will need to be appropriately integrated into the institutional design of the federal regulatory process. ${ }^{10}$ Decisions about the design and implementation of new technologies will therefore need to take into account the legal, political, and managerial dimensions of the rulemaking process. In addition, to take full advantage of new technologies, existing institutional structures and rulemaking practices may themselves need to be reconfigured. For these reasons, effective deployment of information to assist with government rulemaking will require an integration of both technological and institutional analysis.

In cooperation with the National Science Foundation's Digital Government Program, the Regulatory Policy Program at Harvard University initiated two major dialogues on the future direction for research on e-rulemaking between researchers and officials from different regulatory agencies: one in Washington, D.C. in March 2002, the

M. Johnson, The Internet Changes Everything: Revolutionizing Public Participation and Access to Government Information through the Internet, 50 ADMIN. L. REV. 277, 282 (1998).

$4 \quad$ Brandon \& Carlitz, supra note 3, at 1422

5 See, e.g., National Performance Review, "IT03: Develop Integrated Electronic Access to Government Information and Services" (Sept. 1993) available at http://govinfo.library.unt.edu/npr/library/ reports/it03.html; National Performance Review, "REG04: Enhance Public Awareness and Participation" (Sept. 1993) available at http://govinfo.library.unt.edu/npr/library/reports/reg04.html.

6 White House Office of Management and the Budget ("OMB"), Implementing the President's Management Agenda for E-Government (April 2003), available at http://www.whitehouse.gov/omb/egov /2003egov_strat.pdf.

$7 \quad$ Cindy Skrzycki, U.S. Opens Online Portal to Rulemaking; Web Site Invites Wider Participation in the Regulatory Process, WASH. POST, Jan. 23, 2003, at E1.

$8 \quad$ See generally OMB website at http://www.whitehouse.gov/omb/inforeg/xmlreports.html; see also Memorandum from OIRA Administrator John D. Graham, to OIRA staff (Oct. 18, 2001) available at http://www.whitehouse.gov/omb/inforeg/oira_disclosure_memo-b.html.

9 E-Government Act of 2002, Pub. L. No. 107-347, 166 Stat. 2899 (2002).

10 See Jane E. Fountain, Building the Virtual State: Information Technology and INSTITUTIONAL CHANGE (2001). 
other at Harvard in January 2003. ${ }^{11}$ These workshops brought together specialists from the information sciences, law, social sciences, and public management, as well as key regulatory officials from more than ten different government agencies. The aim was to forge a forward-looking research agenda needed to improve the rulemaking process through the development and deployment of information technologies.

The workshop sessions elicited broad recognition from participants about the significance of e-rulemaking as a new arena for research and policy development. These sessions also helped build linkages across research communities and connect researchers who are already beginning to pursue new, interdisciplinary research on the role of information technology in the rulemaking process. This article summarizes the discussions that took place at the Regulatory Policy Program's workshops, with the aim of broadening still further the community of researchers and policy analysts who can contribute to this new area.

Part I of this article details the rulemaking process, outlining the procedures agencies must currently follow in developing new regulations and highlighting some of the problems generally associated with rulemaking. Part II considers ways that information technology may be able to improve the rulemaking process, as well as discusses some of the chief goals, choices, and challenges associated with e-rulemaking. Part III presents a cross-disciplinary agenda for research intended to contribute to erulemaking's long term potential for improving government regulation and enhancing the management and legitimacy of the rulemaking process.

\section{The Emergence of E-Rulemaking}

Until about the middle of the twentieth century, regulatory agencies in the United States frequently established regulatory policy by following court-like procedures and deciding individual cases involving particular regulated parties. ${ }^{12}$ By adjudicating cases involving individual firms, regulatory agencies would effectively establish new "rules," but they would do so by creating precedents to guide other firms in similar industrial sectors. ${ }^{13}$ With the adoption in 1946 of the Administrative Procedure Act (APA), however, Congress specifically authorized agencies to issue general rules outside the context of individual case adjudication and even without adhering to formal court-like procedures. ${ }^{14}$ Although the APA still allowed agencies to engage in adjudication and use formal processes, it also permitted agencies to use an informal rulemaking process which required little more than that agencies provide notice of proposed new rules and give the public an opportunity to comment on them. ${ }^{15}$ This meant that regulatory agencies no

11 For more information about these workshops, including presentations and related materials, see www.e-rulemaking.org.

12 See Kenneth Culp Davis, Administrative Law Treatise, $\$ 1.6$, at 22 ( $3^{\text {rd }}$ ed., 1994); Todd D. Rakoff, The Choice Between Formal and Informal Modes of Administrative Regulation, 52 ADMIN L. REV. $159,163(2000)$.

13 Id.

14 Administrative Procedure Act (“APA”), 5 U.S.C. $\$ 553$ (2000).

15 In order to issue a rule, a regulatory agency must simply: (1) publish a "[g]eneral notice of proposed rule making ... in the Federal Register;" (2) “give interested persons an opportunity to participate 
longer had to search for a suitable individual case before setting general policy and that the agency could follow simpler procedures in creating new rules.

By the 1960s and 1970s, a period during which Congress established a number of new regulatory agencies and statutes, informal rulemaking had become one of the most significant methods for establishing regulatory policy in the United States. ${ }^{16}$ Kenneth Culp Davis declared informal rulemaking to be "one of the greatest inventions of modern government."17 Through informal rulemaking, regulatory agencies have issued rules governing the quality of drinking water, the safe operation of airlines, and the installation of air bags in automobiles, among many other significant policy issues. In fact, over the past several decades, regulatory agencies have adopted about ten times more rules than Congress has passed laws, even though both have the same binding legal effect on regulated entities. ${ }^{18}$

If informal rulemaking was one of the greatest inventions in modern government, information technology now offers the potential to improve on this invention. The basic characteristics of rulemaking - its complexity and information dependence - make it reasonable to expect that agencies could benefit from more extensive use of information technology. This Part develops those characteristics and chronicles the emergence and potential of e-rulemaking.

\section{A. Key Characteristics of Rulemaking}

The three steps in the informal rulemaking process - notice, comment, and final rule - apply across nearly all federal regulatory agencies. Yet in reality, the practice of rulemaking is both procedurally and institutionally more complicated and varied than the rulemaking procedures outlined in the APA suggest. ${ }^{19}$ For one thing, the APA procedures only cover a part of the chronology of rulemaking, beginning with the notice

in the rule making through submission of written data, views, or argument;" and (3) "[a]fter consideration of the relevant matter presented, ... incorporate in the rules adopted a concise general statement of their basis and purpose." Id. These three basic steps provide the procedural contours of what has aptly become known as "notice-and-comment," or informal, rulemaking. Under notice-and-comment rulemaking, the agency first informs the public of its intentions by publishing a notice of proposed rulemaking (NPRM) in the Federal Register and specifying in that notice a time period for the public to submit comments on the proposed rule. After reviewing all the comments received, the agency makes any revisions to the proposed rule and publishes its final rule in the Federal Register. In the main body of the Federal Register announcement - a section referred to as the preamble - the agency provides a written justification for the rule in its final form and an explanation of the policy choices it represents. The Administrative Procedure Act gives those who will be affected by a new rule an opportunity to challenge that rule in the courts. 5 U.S.C. $\$ 702$ (2000). Other statutes and executive orders provide additional procedures that agencies must follow. See infra notes 25-27 and accompanying text.

16 See Cornelius M. Kerwin, Rulemaking: How Government Agencies Write LAw AND MAKE POLICY 13-16 (3d ed. 2003).

171 KenNeth Culp Davis, Administrative LaW Treatise $\$ 6.15$, at 283 ( $1^{\text {st }}$ ed. Supp. 1970).

18 OMB has reported that from October 12001 to September 30, 2002, the federal government published 4,153 new rules. OMB, Informing Regulatory Decisions, supra note 2, at 6. Over the same period, Congress enacted 245 statutes. See Pub. L. 107-45 (Oct. 1, 2001); Pub. L. 107-229 (Sept. 30, 2002). See also Bill Walsh, Unelected Make the Laws; Agencies' Rules Far Outnumber Congress', TIMES PICAYUNE, Aug. 7, 2003, at 10 (noting 269 new laws and over 4,000 new rules over the past year).

19 See Kerwin, supra note 16, at 70. 
of proposed rulemaking (NPRM) and ending with the publication of the final rule, when much, if not most, of the work takes place prior to the development of the NPRM. ${ }^{20}$ Furthermore, the rulemaking process does not necessarily end with the publication of the final rule in the Federal Register. ${ }^{21}$ Organizations with objections to the rule can and do file legal challenges, and courts can and do send rules back to agencies if they find the rules conflict with legal standards. ${ }^{22}$ In response, agencies will revise their rules even after they have been made "final" in the Federal Register. ${ }^{23}$ Moreover, as agencies implement and apply new rules, they often learn of ways that the rule needs to be modified and therefore start a new rulemaking proceeding to amend the existing rule. ${ }^{24}$ In this way, the rulemaking process is iterative and ongoing.

In addition to starting earlier and extending longer than the APA would suggest, rulemaking has become more complicated than the APA's notice-and-comment framework because Congress, the President, and the courts have imposed a number of additional rulemaking requirements on agencies. ${ }^{25}$ For example, since 1981, agencies have been required by executive orders issued by the President to conduct economic analysis of major or significant proposed regulations and to have their analyses reviewed

20 See Kerwin, supra note 16, at 179-92. See, e.g., Thomas O. McGarity, "The Internal Structure of EPA Rulemaking" 54 LAW AND CONTEMP. PROBS. 57 (1991). Decisions need to be made about whether to develop and what priority it should be given on the agency's agenda. Twice each year, agencies publish a "regulatory agenda" in the Federal Register, which lists brief information about all the rules each agency is contemplating or in the process of developing. Regulatory Flexibility Act, 5 U.S.C. $§ 602$ (2000); see e.g. 68 Fed. Reg. 30920 (May 27, 2003). The semiannual regulatory agenda usually provides the first public notification that the agency is developing a proposed rule. In some cases, agencies issue an Advance Notice of Proposed Rulemaking, providing more detailed information than in the regulatory agenda and encouraging the public to provide early comment prior to the issuance of the proposed rule. As they develop their proposals, agencies need to gather information and conduct analysis of the underlying problem and on possible regulatory solutions, a process that can be time consuming. During this time, agency staff members frequently engage in consultations with regulated firms and their representatives, as well as with other interested parties and other executive branch or legislative staff.

$21 \quad$ Cary Coglianese, Assessing the Advocacy of Negotiated Rulemaking: A Response to Phillip Harter, 9 N.Y.U. ENVTL. L.J. 410 (2001). After the final rule appears in the Federal Register, the operative text of the rule - without any of the preamble - is subsequently published in the appropriate section of the Code of Federal Regulations.

22 APA, 5 U.S.C. $\$ 706$ (2000). The Administrative Procedure Act provides that all agency rules are subject to judicial review and other statutes permit organizations to file lawsuits challenging certain rules even before the agency enforces them. APA, 5 U.S.C. $\$ 702$ (2000).

23 See Coglianese, supra note 21, at 410-11. Of course, subsequent revisions to rules must also follow the notice-and-comment procedures and appear in the Federal Register.

$24 \quad I d$.

25 Additional procedural requirements or arrangements can be found in, among other sources, the National Environmental Policy Act, 42 U.S.C. $\$ 4332$ (2000), Paperwork Reduction Act, 44 U.S.C. $\S 33501-$ 21 (2000), Freedom of Information Act, 5 U.S.C. $\$ 552$ (2000), Federal Advisory Committee Act, 5 U.S.C. App. $2 \S \S 1-16$ (2000), Negotiated Rulemaking Act, 5 U.S.C. $\S \S 561-570 a$ (2000), Government in the Sunshine Act, 5 U.S.C. $\S 552(\mathrm{~g})(\mathrm{h})$ (2000), and Congressional Review Act, 5 U.S.C. $\S \S 801-808$ (2000). It is widely believed that the cumulative effect of these myriad procedures has been to "ossify" or slow down the rulemaking process. See, e.g., Jerry L. MASHAW \& DAVID L. HARFST, The Struggle FOR Auto SAFETy (1990); Thomas O. McGarity, Some Thoughts on Deossifying the Rulemaking Process, 41 DuKE L. J. 1385-1462 (1992). 
by the Office of Management and Budget (OMB) ${ }^{26}$ These executive order requirements have been effectively codified by the Unfunded Mandates Reform Act, passed by Congress in 1995, which also requires agencies to analyze the costs and benefits of any proposed regulation that would impose annual costs of more than $\$ 100$ million on the economy. ${ }^{27}$ As a result, OMB's Office of Information and Regulatory Affairs plays a key role in reviewing, and sometimes asking for revisions of, significant proposed and final rules before agencies publish them in the Federal Register. ${ }^{28}$

Taken together, the various requirements from statutes, executive orders, and court decisions make the rulemaking process much more complex than the terms "informal" or "notice-and-comment" rulemaking might otherwise imply. ${ }^{29}$ The complexity of rulemaking holds at least two important implications for the use of information technology in this governmental process. First, the complexity of rulemaking creates institutional and decision making challenges that information technology may help regulatory agencies overcome. Second, designing information systems that will be used effectively by regulatory agencies requires a clear understanding of the complex institutional environment within which rulemaking takes place. In other words, the development of effective e-rulemaking demands institutional analysis as well as technological research. To ensure the design of effective erulemaking initiatives, it will therefore help to keep in mind the salient characteristics of rulemaking and the problems often associated with rulemaking that information technology might help address.

One of the most notable characteristics of rulemaking is its information intensity. Rulemaking presents government decision makers with some of society's most pressing issues that demand extensive information collection and analysis. ${ }^{30}$ In addition, government agencies address many routine issues through rulemaking and, while each of these routine rules may demand little in the way of new information, in the aggregate these more routine rules can place significant processing demands on regulatory agencies. Rulemaking is not only information-rich, but it is particularly rich in language-based information. After all, rules themselves are text, as are public comments and other communications with the various governmental and nongovernmental participants in the rulemaking process. Although the APA requires only "a concise general statement" of the basis of the rule, preambles for the most significant rules can take up many more pages in the Federal Register than the rules themselves, occasionally even taking up a hundred pages or more for a single new rule. ${ }^{31}$ The volume of both text-based and data-based background information associated with even a single rulemaking can be vast and varied in format, but must nevertheless be maintained in an accessible way in an agency docket.

Information used in rulemaking is varied because many different types of individuals and institutions are involved in the process. Developing rules requires cooperation across different offices and staffs within a regulatory agency, each with their

26 Exec. Order No. 12,291, 46 Fed. Reg. 13,193 (Feb. 17 1981); Exec.Order No. 12,886, 58 Fed. Reg. 51,735 (Sept. 30 1993).

$27 \quad$ Unfunded Mandates Reform Act, 2 U.S.C. $\$ 1532$ (2000).

28 See Robert W. Hahn \& Cass R. Sunstein, A New Executive Order for Improving Federal Regulation? Deeper and Wider Cost-Benefit Analysis, 150 U. PeNN. L. Rev. 1489, 1517 (2002).

$29 \quad$ See generally McGarity, supra note 25.

$30 \quad$ See Rakoff, supra note 12, at 165.

31 See, e.g., 55 Fed. Reg. 22,520 (June 1, 1990). 
own needs and professional expertise. The development and implementation of a new rule is usually an interdisciplinary effort, with different types of analysts - legal, economic, and scientific - contributing to the process. Furthermore, actors from outside the agency -- various governmental oversight bodies, such as the OMB, Congress, and the courts -- provide relevant information to agency decision makers. Interest groups, business firms, and the press also factor into deliberation and decision making. ${ }^{32}$ Moreover, the process of developing a new rule is supposed to be transparent to those outside the government, which creates a demand for communicating information effectively. Finally, the end product of the process - the rule itself - must also be communicated to hundreds of thousands of users, both inside and outside of government.

In one form or another, the tasks of gathering, processing, analyzing, and communicating information make up most of the administrative costs associated with rulemaking. For many government agencies, information management can be a significant burden. ${ }^{33}$ Early input from interested parties often depends on in-person meetings which can be costly and time-consuming to organize. As a result, these kinds of consultations may not be held as frequently as might be optimal. When members of the public offer formal comments on rules, they have been expected until recently to file their comments in hard copy format (sometimes in triplicate), delivered by hand or by mail. ${ }^{34}$ As with public comments, communication of key analyses and drafts between government officials, such as between agency staff and OMB, also often takes place by exchanging hard copies, often delivered by couriers. Furthermore, regulatory agencies' dockets consist literally of large rooms of file cabinets, sometimes with documents later archived on microfiche also filed in cabinets. These docket rooms are cumbersome to access by those outside of the agency, especially those living outside Washington, D.C. At least until recently, agencies' proposed and final rules themselves were relatively inaccessible to the general public, with access limited to hard copies of the Federal Register and Code of Federal Regulations, which were available only at certain public or law libraries. 35

Perhaps in part due to information management burdens, government regulation has come in for substantial criticism over the past few decades. For some observers, the expanding sweep of government regulation has become unacceptably incoherent and inefficient. ${ }^{36}$ Problems of poor data quality and inconsistent reporting are sometimes said to increase problems of regulatory incoherence. ${ }^{37}$ Still others have argued that the rulemaking process has become ossified, pointing out that rulemaking has become more burdensome and time-consuming than the informal, notice-and-comment framework of

\footnotetext{
32 See Kerwin, supra note 16 , at 182-4.

33 See Kerwin, supra note 16, at 144-47.

34 See, e.g., "Hazardous Waste Management System; Testing and Monitoring Activities" 55 Fed. Reg. 4440 (Feb. 8, 1990) (requiring comments in triplicate).

35 See Government Printing Office website at http://www.gpoaccess.gov/fdlp.html.

36 See Stephen Breyer, Breaking the Vicious Circle (1992); John F. Morrall III, A Review of the Record, 10 REG. 25 (1986).

37 On the problem of incoherence in regulatory policymaking, see Cary Coglianese, Bounded Evaluation: Cognition, Incoherence, and Regulatory Policy, 54 STAN. L. REV. 1217 (2002).
} 
the APA seemed to suggest, especially for agencies with shrinking budgets. ${ }^{38}$ In addition, in the face of resource constraints, extensive engagement with the public has not always been regulators' top priority. Yet some have argued that regulatory policy - made by unelected government officials - suffers from a democratic deficit. ${ }^{39}$ With more extensive and effective public participation, agencies may gain insights needed to craft better regulatory policy as well as be able to enhance the perceived legitimacy of government regulation. ${ }^{40}$ Given the controversial and significant policy choices embedded in regulatory policy, any information technologies that can improve agency management and enhance public participation seem likely to help in addressing the criticisms of rulemaking and promoting more effective, efficient, and legitimate regulatory policy.

\section{B. The Rise of E-Rulemaking}

Attention to the use of information technologies in government rulemaking dates back only about a decade. Beginning in the late 1980s, the now-defunct Administrative Conference of the United States started commissioning reports prepared by administrative law scholar Henry Perritt on the application of information technology to different aspects of government record-keeping and rulemaking. ${ }^{41}$ The Clinton Administration's National Performance Review issued reports in the early 1990s calling upon federal agencies to increase their use of information technology in developing and implementing regulations. ${ }^{42}$ In 1994, the Office of the Federal Register made the Federal Register available free to the public via the Internet, with the Code of Federal Regulations going on-line shortly thereafter. ${ }^{43}$ By the mid-1990s, Congress also began to take action, adopting amendments to the Paperwork Reduction Act and the Freedom of Information Act that aimed to increase the availability of government agency information via the Internet. ${ }^{44}$

During this same period, regulatory agencies themselves began to take advantage of advances in information technologies. ${ }^{45}$ Many agencies, for example, began to use email to send and edit documents internally when designing new rules. Some agencies developed electronic word processing "templates" to encourage more standardized

38 See, e.g., Thomas O. McGarrity, Some Thoughts on "Deossifying the Rulemaking Process," 41 DUKE L.J. 1385 (1992); see also Jerry L. Mashaw, Improving the Environment of Agency Rulemaking: An Essay on Management, Games, and Accountability, 57 J. L. \& CONTEMP. PROB. 185 (1994).

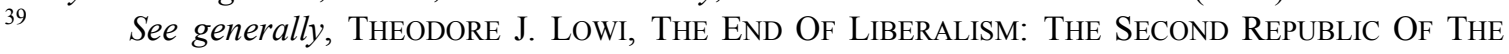
United States (1979); DAVID Schoenbrod, Power Without ResPonsibility: How Congress Abuses The People Through Delegation (1993).

$40 \quad$ See Kerwin, supra note 16 , at 158.

41 See Henry H. Perritt, JR., Report to the AdMinistrative CONFEREnce of the United StATes, Electronic Dockets: The USE OF InFORMATION TECHNOLOGY IN RULEMAKING AND AdjudicAtion, (1995); Henry H. Perritt, JR., Report to the Administrative Conference OF the United States, Federal Agency Electronic Records Management And Archives (1990).

42 See NATIONAL PERFormance ReView, supra note 5.

43 See Government Printing Office website at http://www.gpoaccess.gov/nara/index.html.

441995 Paperwork Reduction Act Amendments, Pub. L. 104-14, 109 Stat. 186 (1995) (codified at 44 U.S.C. $\S \S 3501-21$ (2000)); Pub. L. No. 104-231, 110 Stat. 3048 (1996) (codified at 5 U.S.C. §552 (2000)).

$45 \quad$ See Brandon \& Carlitz, supra note 3. 
reporting of information in rulemaking documents. Agencies also began to use the Internet to enhance transparency and public participation in rulemaking. Some began posting key studies and other rulemaking documents on their websites. Others used information technology to analyze public comments submitted on proposed rules. For example, the Bureau of Land Management used scanning technologies to process more than 30,000 public comments on a proposed rangelands rule. ${ }^{46}$ Still other agencies began to allow the public to submit comments via email. For example, the Food and Drug Administration used electronic scanning of documents in its 1996tobacco marketing rulemaking, ${ }^{47}$ and email comments played a role in the Federal Aviation Administration's rulemaking on small-scale rockets, ${ }^{48}$ and the Department of Agriculture's rulemaking on the labeling of organic foods. ${ }^{49}$ Other early adopters of electronic commenting included the Nuclear Regulatory Commission and the Federal Communications Commission. ${ }^{50}$

In 1998, the Department of Transportation (DOT) became the first regulatory agency to make available an on-line, department-wide regulatory docket, providing full access to all studies, comments, and other documents contained in the agency's rulemaking records. ${ }^{51}$ The DOT system also allows the public to submit electronic comments on all rules proposed by the department. A few years later, the Environmental Protection Agency (EPA) also adopted an agency-wide system. ${ }^{52}$ Several other agencies have begun implementing similar docket management systems.

These early e-rulemaking efforts have captured the attention of academic researchers as well as policymakers. In 1998, the Administrative Law Review published an article by law professor Stephen Johnson who predicted that the Internet would "change everything" when it came to public participation in federal rulemaking. ${ }^{53}$ A few years later, the National Science Foundation's Digital Government Program, together with Drake University and the Council for Excellence on Government, helped launch the first gathering of academics and agency managers to discuss long-term research needs on information technology and rulemaking. ${ }^{54}$

$46 \quad$ See Kerwin, supra note 16, at 194.

$47 \quad 60$ Fed. Reg. 41314 (proposed Aug. 11, 1995)

48 Press Release, Federal Aviation Administration, FAA First-Ever-On-Line Public Forum Proves Successful in Gaining Rulemaking Input (Mar. 30, 2000) available at http://www1.faa.gov/apa/pr/pr.cfm?id=1009.

4962 Fed. Reg. 65859 (Dec. 16, 1997) ; see also Stuart W. Shulman, An Experiment in Digital Government at the United States National Organic Program, .20 AGRIC. \& HUM. VAlues (forthcoming fall 2003).

50 See Michele Ferenz \& Colin Rule, RULENET: An Experiment in Online Consensus Building, in The Consensus Building HANDBOOK: A COMPREHENSIVE Guide to ReACHING AgreEMENT 879 - 98 (Lawrence Susskind et al. ed., 1999); JoAnne Holman \& Michael A. McGregor, "Thank You for Taking the Time to Read This:" Public Participation via New Communication Technologies at the FCC, 2 JOURNALISM \& COMM. MONOGRAPHS 158 (2001).

51 See U.S. Department of Transportation, DePartment of TRANSPORTation's Docket MANAGEMENT SYSTEM, at http://www.diggov.org/archive/library/dgo2001/DGOMAC/MEDIA/MEERS.PDF.

52 See U.S. Environmental Protection Agency website at http://cascade.epa.gov/RightSite/dk_public_home.htm.

${ }_{53}$ Johnson, supra note 3.

$54 \quad$ See Drake University website $a t$ http://www.drake.edu/artsci/faculty/sshulman/DC2001. 
In a major effort to expand information technology capabilities across the federal government, the Bush Administration launched an e-government initiative as part of the President's Management Agenda. ${ }^{55}$ The Administration's e-government initiative, which is being coordinated through the Office of Management and Budget, consists of approximately two dozen projects, one of which is e-rulemaking. ${ }^{56}$ A key goal for the Administration's e-rulemaking project is to make it easier for the public to access information about government regulations and participate in the rulemaking process. ${ }^{57}$ In addition, Administration officials believe that better use of information technology will also improve regulatory decisions and increase the quality of government rules.

OMB selected EPA to be the interagency team leader on the Administration's erulemaking project, with a core group of other agencies playing key roles as well. The project consists of three stages. The first stage, which was completed in January 2003, involved the creation of a search-and-comment portal located at www.regulations.gov. ${ }^{58}$ The Regulations.Gov portal relies on the Office of Federal Register's listings of notices of proposed rules and enables users to search all proposed rules that are open for public comment. Building on software originally developed by the Food and Drug Administration, EPA hosts a comment processing system that enables members of the public to comment on any proposed rule issued by any government agency, all from a single location on the Internet. ${ }^{59}$ Comments submitted electronically at Regulations.Gov are then distributed to the relevant agencies.

The second stage of the Bush Administration's e-rulemaking project will expand on the first stage efforts to create a government-wide e-docket system. The administration's current plan is to enhance the EPA's EDOCKET system to take into account the docketing requirements of other agencies and eventually to create a comprehensive on-line docket that will enable the public to access all documents related to every new regulation across the government. ${ }^{60}$ Administration officials expect that the development of a government-wide e-docket will be followed by a third stage involving the development of an "electronic desktop" for regulators. Plans for this third stage have yet to be fully developed, but this final stage reflects the administration's long-term goal of creating a suite of knowledge management tools to aid with regulatory analysis and decision making. ${ }^{61}$

55 See OMB, The President's Management Agenda, Fiscal Year 2002, available at http://www.whitehouse.gov/omb/budget/fy2002/mgmt.pdf ; see also OMB supra note 6. Like other aspects of the President's Management Agenda, implementation of e-government initiative are scored by OMB on a 'traffic light' system. See Stephen Barr, In Mid-Year Score-Card Assessment, Some Agencies Miss the Mark, WASH. POST, July 29, 2002 at B2.

56 See OMB, The President's Management Agenda, Fiscal Year 2002, available at http://www.whitehouse.gov/omb/budget/fy2002/mgmt.pdf.

57 See OMB supra note 6, at 26.

$58 \quad$ See Skrzycki, supra note 7.

59 See Rick Otis, e-Rulemaking, Presentation to John F. Kennedy School of Government Workshop on E-Rulemaking (Jan. 21, 2003), at http://www.ksg.harvard.edu/cbg/Conferences/rpp_rulemaking/Otis

Presentation.pdf; Oscar Morales, eRulemaking Initiative: Trials and Tribulations of a Frustrated Bureaucrat or the Proof is in the Details, Presentation to John F. Kennedy School of Government Workshop on ERulemaking (Jan. 21, 2003), at http://www.ksg.harvard.edu/cbg/Conferences/rpp_rulemaking/Morales_ presentation.pdf.

$60 \quad$ See Otis, supra note 59; Morales supra note 59.

$61 \quad$ See Otis, supra note 59; Morales supra note 59. 
The current administration's efforts in e-rulemaking seem likely to be continued in future years due to the passage of the E-Government Act in 2002. ${ }^{62}$ This law aims to promote the use of information technologies throughout government in order to increase opportunities for public participation, improve government decision making, and enhance the ability of government agencies to achieve their programmatic and policy goals. The Act specifically directs regulatory agencies to accept electronically submitted comments and to establish comprehensive electronic dockets for all rulemakings. ${ }^{63}$ The Act also creates a new office of Electronic Government within OMB, requires that office to produce guidelines for all agency websites, and generally calls upon agencies to adopt innovative uses of information technologies. ${ }^{64}$

\section{E-Rulemaking's Potential}

Despite all the efforts to promote the use of e-rulemaking, these early steps toward e-rulemaking only scratch the surface of what information technology makes possible. To begin with, the advances reflected in the e-docketing systems installed by agencies such as DOT or EPA are by no means the norm across the federal government. Only a handful of agencies have developed automated docketing systems and, even among the ones that have, some agencies have used such dockets only for a select number of rules. ${ }^{65}$ Furthermore, even though Regulations.Gov now permits the public to file electronic comments on any new proposed rule, in some agencies any comments submitted through Regulations.Gov must still be printed out by government staff and stored in hard copy in cumbersome file cabinets or converted to microfiche. ${ }^{66}$

More significantly, even the most advanced applications of information technology in government rulemaking, such as the DOT or EPA's docket systems, only capture a small part of the potential uses for information technology in the regulatory process. As a participant in an e-rulemaking workshop organized by Harvard's Regulatory Policy Program noted, e-rulemaking can be much more than just a "bunch of websites." Advances in information technology make it possible to retrieve, categorize, extract, and analyze information in markedly more effective ways that would help dramatically improve government rulemaking. ${ }^{67}$

As noted earlier, developing a regulation requires agency analysts and rule writers to review a large volume of studies, public comments, and other relevant documents. To manage this information more effectively, agency analysts could rely more extensively

\footnotetext{
62 E-Government Act of 2002, Pub. L. No. 107-347, 166 Stat. 2899 (2002).

Id.

Id.

See Brandon \& Carlitz supra note 3, at 1433-35.

See GaO, Electronic Rulemaking: EfForts to Facilitate Public Participation Can be Improved, Report to the Committee on Governmental AfFairs, U.S. Senate (Sept. 17, 2003) available at $\mathrm{http} / / / \mathrm{www} . g a o . g o v /$ new.items/d03901.pdf.

67 See Eduard Hovy, e-Rulemaking: Research Problems for IT, Presentation to the National Conference on Digital Government Research (May 20, 2003), at http://www.ksg.harvard.edu/cbg/Conferences/rpp_rulemaking/Hovy_Presentation_Fnl.pdf; Elizabeth D. Liddy, 30 Applications of Information Technology to E-Rulemaking, Presentation to the National Conference on Digital Government Research (May 20, 2003), at http://www.ksg.harvard.edu/cbg/Conferences/rpp_rulemaking/Liddy_Applications_IT.pdf.
} 
on ad hoc information retrieval (IR) systems to identify relevant information. ${ }^{68}$ IR systems -- one of the most well-known is the popular search engine Google -- allow the information user to input a query, and then the system searches all the documents based on the query and returns matching documents. ${ }^{69}$ If some of the documents are in a foreign language, machine translation technology could be used to help translate the gist of these documents into the language of the user. ${ }^{70}$

Once information is retrieved through an IR system, it needs to be organized, a process which can also be automated. For example, text categorization systems could sort public comments according to the different issues presented in a rulemaking. In other contexts, state of the art text categorization systems can organize documents into dozens of categories with upwards of about $85 \%$ accuracy. ${ }^{71}$

For many purposes, the relevant information contained within a given rulemaking document will often consist of only a small fraction of the entire document. To gather only the most pertinent information from each relevant document, agencies could rely on information extraction systems to pull out these key parts. These key parts can themselves be used as "metadata" which can be used to organize the documents still further in ways that may be useful to the rule writer. ${ }^{72}$ In this way, computer systems could enable users to retrieve focused and relevant information from all the comments, background documents, and studies relevant to each sub-provision of a new rule, as well as to provide summarization and analysis of this information.

In addition to systems that retrieve, categorize, and extract information, other natural language processing systems could be of value to government regulators. ${ }^{73}$ For example, some information systems allow the public to submit questions and receive the answers (in addition to documents that contain the answers). Still other technologies are beginning to be able to produce summaries of large documents, condensing a high volume of information into a form that can make them more useable for busy decision makers.

Greater use of these natural language processing systems will also facilitate increased development of relevant digital libraries. ${ }^{74}$ Digital libraries contain information in multiple media formats and have the flexibility needed to make the

See Claire Cardie, Natural Language Technologies for E-Rulemaking, Presentation to John F. Kennedy School of Government Workshop on E-Rulemaking (Jan. 21, 2003), at http://www.ksg.harvard.edu/cbg/Conferences/rpp_rulemaking/Cardie_Presentation.pdf.

69 RiCARDO BAEZA-YATES \& BERTHIER RIBIERO-NETO, MODERN INFORMATION RETRIEVAL (1999).

70 Bonnie J. Dorr \& Douglas W. Oard, Evaluating Resources for Query Translation in CrossLanguage Information Retrieval, Proceedings of the First International Conference on Language Resources and Evaluation 759-763 (1998), available at ftp://ftp.umiacs.umd.edu/pub/bonnie/granadaps-a.pdf.

$71 \quad$ See Cardie supra note 68, at 13.

72 See Murtha Baca, ed., Introduction to Metadata: Pathways to Digital Information (1998).

${ }^{73}$ See Boris Katz et al., Better Public Policy Through Natural Language Information Access, MIT Artificial Intelligence Laboratory (2003) at http://www.ksg.harvard.edu/cbg/Conferences/rpp_rulemaking/Hurwitz_LanguageInfo_Access.pdf.

74 See Edward A. Fox, Digitial Libraries for e-rulemaking: Integrating the Information Fields (Hypertext, Information Retrieval, Multimedia, etc.), Presentation to John F. Kennedy School of Government Workshop on E-Rulemaking (Jan. 21, 2003) at http://www.ksg.harvard.edu/cbg/Conferences/rpp_rule-making/Fox_Presentation.pdf. 
information available to a large number of users. ${ }^{75}$ The use of digital libraries and advanced information retrieval systems could help regulatory agencies more effectively share common information across different program offices and even across different rulemakings.

Overall, many possibilities exist for applying information technologies in new ways to government rulemaking. Throughout Harvard workshops, participants identified a number of innovations in rulemaking practice that could be developed either with new or existing technologies. Some of these ideas included:

- Improved data mining capabilities. Many agencies keep compliance or incident data, but the staff who write rules often have to travel to regional offices to get this information. Data mining technologies - which range from simple web search engines to more sophisticated multi-database search and integration systems - could enable rule writers to learn from the various data sources available throughout their agencies. ${ }^{76}$

- Conflict identification tools. Information technology could help rule drafters identify certain obvious conflicts in rules, to help ensure consistency both within and across rules. Also, expert systems and software that creates representations and inferences from texts could spot differences between proposed and final rules to help agencies ensure that they have provided adequate notice of any changes before promulgating the final version. ${ }^{77}$

- Plain language tools. To help make rules clearer, automatic "plain English" (or other language) translators could be developed that aid agency staff in drafting rule language. Current natural language technology is still limited in its translation ability, but highly specified applications appear possible in the near term. $^{78}$ Such tools could also eventually be used to assist with regulatory compliance.

- Integrating rules with other laws and supporting material. Information technology could link all the traces of a rule's history, both back to the statute as well as to past or related rules. ${ }^{79}$ Similarly, agencies could provide on-line links that relate specific provisions of a rule back to the agency's justification for or discussion of those provisions in the rule's preamble. Recent advances in topic

75 See EDWARD A. Fox, ED., Sourcebook ON DigitAl Libraries (1993), available at ftp://fox.cs.vt.edu/pub/DigitalLibrary/DLSB.pdf.

76 For overviews of data mining, see DAvid J. HAND, HEIKKI MANNILA, PadhraiC SMYTH, Principles of Data Mining (2001) and Marti A. Hearst, Text Data Mining, in Ruslan MitKov, ED., The OXFORD HANDBOOK OF COMPUTATIONAL LINGUISTICS 616 (2003).

77 Conflict identification can also be used in compliance assistance. For a description of a system that can identify conflicts between rules and users' performance, see Shawn Kerrigan, Charles Heenan, and Kincho H. Law, Regnet: An Infrastructure for Regulatory Information Management and Compliance Assistance, Proceedings of the National Conference on Digital Government Research, Los Angeles, CA, pp. 377-382, 2002. http://eil.stanford.edu/publications/shawn_kerrigan/DGO2002_FinalPaper_Kerrigan_Heenan_Law.pdf

$78 \quad$ See generally Ehud Reiter and Robert Dale, Building Applied Natural Language Generation Systems. 3 J. NAT. LANG. ENGIN. 57 (1997), available at http://www.ics.mq.edu.au/ rdale/publications/papers/1997/jnle97.pdf.

79 See Jeffrey S. Lubbers, The Future of Electronic Rulemaking: a Research AgENDA, (2002) at http://www.ksg.harvard.edu/cbg/research/rpp/RPP-2002-04.pdf. 
detection and tracking have made it possible to automate this cross-linking function to a limited extent. ${ }^{80}$

- Customizable, automatic alerts. Long before an agency issues a notice of proposed rulemaking, it announces its intentions in the semiannual regulatory agenda. ${ }^{81}$ Interested users could sign up for email alerts of rules added to an agency's regulatory agenda. In addition, when a user visits a website for a particular rule, agency systems could inform the user about other rules that those visiting the same website have visited (much like what Amazon.com ${ }^{\circledR}$ does for books). ${ }^{82}$

- Online regulatory negotiations or juries. Digital technology might be used to replicate the kind of deliberation that traditionally takes place in juries. Regulatory officials could enlist randomly selected panels of citizens with the task of advising on core values raised by a rulemaking. ${ }^{83}$

- Digital public hearings. One participant spoke of a rulemaking that affected various Native American tribes in Alaska and recounted the difficulties the agency and the tribes experienced in their consultations. Technologies such as bulletin boards or user profiling systems could facilitate communication in such situations or any time a rule affects a dispersed portion of the public, such as small businesses.

- Sharing data and models online. Using something akin to the popular SimCity ${ }^{\circledR}$ game, regulatory agencies could provide the public with digital access to simulation software that reflects the agency's modeling of its regulatory problem. ${ }^{84}$ The use of such software could help educate the public about the tradeoffs implicit in the rulemaking and thereby potentially offer more informed comments on significant new rules.

- “TurboTax ${ }^{\circledR}$ ” rules. Information technology could lead to a reconceptualization of the form in which rules are promulgated, transforming rules from text contained in the CFR to software packages akin to the popular TurboTax ${ }^{\circledR}$ or other commercially available compliance software. Researchers at Stanford University have demonstrated how wheelchair accessibility standards could be defined using software that simulates in-use performance rather than by textbased rules. 85

- Information technology and non-rule policies. Agencies issue many policy statements and guidance documents that are not formally rules, but these non-rule

80

For a good overview of topic detection and tracking, see Charles L. Wayne, Topic Detection and Tracking (TDT): Overview and Perspective, presented at the DARPA Broadcast News Transcription and Understanding Workshop (1998), available at http://www.nist.gov/speech/publications/darpa98/pdf/tdt10.pdf

$81 \quad$ See Regulatory Flexibility Act, 5 U.S.C. $\$ 602$ (2000).

$82 \quad$ See Liddy, supra note 67.

83 See Cary Coglianese, The Internet and Public Participation in Rulemaking, Regulatory Policy Program Working Paper RPP-2003-05, (2003) at http://www.ksg.harvard.edu/cbg/research/rpp/RPP-200305.pdf

84 See Keith Belton, What if Everyone Were a Policy Analyst, 23 REG. Fall 2000 at 8-9.

85 Charles S. Han et al., A Performance Based Approach to Wheelchair Accessible Route Analysis, 16 AdVANCED ENGINEERING INFORMATICS 53 (2002). 
policies may sometimes be nearly as important as rules. ${ }^{86}$ Automated text summarization technology could be used to improve the accessibility, transparency, and management of these policies just as with rules. ${ }^{87}$

As these examples of potential innovations suggest, current e-rulemaking efforts are but first steps toward the full exploitation of information technology. Making regulatory dockets available on-line and allowing citizens to submit electronic comments can certainly help make it easier for the public to follow government rulemaking and agencies to manage their information, but these early steps have only barely begun to tap the full potential for existing and new forms of information technology in the rulemaking process.

\section{E-Rulemaking: Prospects and Challenges}

Although advances in information technology raise many possibilities for changes in rulemaking practice, deciding whether to pursue any of these alternatives raises the question of what e-rulemaking should seek to accomplish. As already noted, erulemaking is generally thought to hold the potential to help improve the management and legitimacy of the rulemaking process. ${ }^{88}$ It may also help in overcoming some of the problems commonly attributed to the rulemaking process, such as those related to incoherence, sluggishness, or lack of transparency. ${ }^{89}$ Future applications of information technology to the rulemaking process will benefit from explicit consideration of what agencies hope to gain from the use of this technology. This Part clarifies the most significant goals for e-rulemaking,, as well as the central issues surrounding the design of new technologies for rulemaking and the key institutional constraints facing the future development of e-rulemaking.

\section{A. Goals for E-Rulemaking}

Addressing some of rulemaking's various challenges, participants at the Regulatory Policy Program's e-rulemaking workshops identified several goals for erulemaking: increasing democratic legitimacy, improving policy decisions, reducing administrative costs, and increasing regulatory compliance. Participants recognized that in order to assess new applications of information technology it will be necessary to compare e-rulemaking against the results that obtain in the absence of the information technology. By making such a comparison based on the core goals goals, as well as specific metrics for measuring progress toward these goals, analysts will be able to

$86 \quad$ See Robert A. Anthony, Interpretive Rules, Policy Statements, Guidances, Manuals, and the Like-Should Federal Agencies Use Them To Bind The Public, 41 DuKE L. J. 1311 (1992); Robert A. Anthony \& David A. Codevilla, Pro-Ossification: A Harder Look at Agency Policy Statements, 31 WAKE FOREST L. REV. 667 (1996); see also United States v. Mead Corp. 533 U.S. 218 (2001).

87 For a discussion of text summarization, see Eduard Hovy, Text Summarization, in RuSLAN MitKov, ED., THE OXFORD HANDBOOK OF COMPUTATIONAL LinQUisTics 583 (2003).

$88 \quad$ See supra Part I.B.

89 See supra notes 36-39 and accompanying text. 
determine whether specific applications of e-rulemaking make a meaningful and positive difference to rulemaking.

Goal 1: Increase Democratic Legitimacy. Even though rulemaking has significant effects on society and the economy, the officials making rulemaking decisions are themselves neither elected nor otherwise immediately accountable to the larger public. $^{90}$ Indeed, career professionals conduct the major analysis and drafting, even though the political appointees heading the agencies do play a role in reviewing and approving key decisions. Yet from the standpoint of democratic legitimacy, the very significance of rulemaking combined with its distance from the public eye make it all the more important that regulatory officials engage the public in the process. In-person public hearings or advisory committee meetings, as well as the conventional comment period, provide the traditional means for public input into the rulemaking process. Information technology may be able to broaden public outreach both by fostering greater public awareness of rulemaking as well as by making it easier for more citizens to add their voices to the decision making process. ${ }^{91}$

Of course, without more, the goal of increasing democratic legitimacy will seem almost too general to assist information systems designers or regulatory officials. Participants characterized this goal in more specific ways which should prove helpful to decision makers and designers, such as: (1) increasing public understanding of rulemaking, (2) increasing both the quality and quantity of public comment on rulemaking, (3) making the public comment process more interactive and deliberative, and (4) enhancing the ability of more democratically accountable institutions, such as Congress or the President, to oversee the rulemaking process.

At present, the public has relatively little understanding of both the rules that specific agencies are developing and the process by which the agencies promulgate their rules. $^{92}$ Yet such knowledge of the issues and the process are essential precursors to participating effectively in government rulemaking. Information technology may provide better ways of communicating the steps of the rulemaking process to the public, notifying them of rules that may affect their work or their lives, and facilitating access to information that will enable members of the public to comprehend the policy choices embedded in rulemaking.

With greater understanding of the issues, the quality of public comments may improve. $^{93}$ For example, instead of comments expressing general support for or opposition to a rule, better-informed members of the public may be able to explain why they support or oppose the rule. That said, at least one workshop participant expressed concern that a goal of increasing the quality of public comments seemed somewhat patronizing.

\footnotetext{
90 See Cary Coglianese, Administrative Law, in PAul B. BAltes \& NeIL J. SMELSER, EDS., INTERNATIONAL ENCYCLOPEDIA OF SOCIAL AND BEHAVIORAL SCIENCES 1:85-88 (2001).

$91 \quad$ See Johnson, supra note 3.

92 See Kerwin, supra note 16. Moreover, media coverage of regulatory policy is limited, see Cary Coglianese \& Margaret Howard, Getting the Message Out: Regulatory Policy and the Press, 3 HARV. Int'L. J. Of Press/Politics 39 (1998); Terry Moe, Political Institutions: The Neglected Side of the Story, 6 J. L. ECON \& ORG. 213 (1990).

93 See Stuart W. Shulman et al., Electronic Rulemaking: New Frontiers in Public Participation, 21 SOC. SCI COMPUTER REV. 162 (2002).
} 
Even without affecting the quality of public comment, information technology could increase the quantity of comments. ${ }^{94}$ Many participants were convinced that information technology would lead to a dramatic increase in the number of comments submitted on agency rules. In addition to bringing about an overall increase in public comments, e-rulemaking could also affect the types of commentators, such as by increasing the proportion of previously underrepresented voices in the rulemaking process. ${ }^{95}$ This is another way that information technology could be seen to increase the democratic legitimacy of rulemaking.

Information technology could also change the way that the public comments on rules, shifting the mode of communication from a relatively unidirectional one to a more deliberative and interactive process. Citizens and government officials could interact with each other in dialogues facilitated through electronic communication technologies. In addition, members of the public could begin to comment on each others' comments as well. ${ }^{96}$

Finally, information technology could enable other institutions and actors to monitor what agencies are doing and seek to influence the direction of regulatory policy. Not only could information make it easier for political appointees within agencies to follow and manage the work of civil service professionals, but it could also facilitate monitoring by congressional committees, White House staff, outside interest groups, and independent analysts. ${ }^{97}$

Given these different ways of characterizing the goal of increased democratic legitimacy, some of the specific metrics that might be used to operationalize legitimacy include:

- Public knowledge about rulemaking process or substantive regulatory issues

- Number of comments submitted

- Distribution of viewpoints or sectors reflected in comments

- Number and type of issues raised in comments

- Frequency of litigation challenging agency rules

- Frequency or type of intervention by Congress or other oversight bodies

- Public support for government regulation

$94 \quad$ See id.

95 The current level of participation by citizens in the rulemaking process is quite limited. In one study of comments submitted in twenty-five EPA rulemakings, comments by individual citizens made up only about $6 \%$ of all the comments filed with the agency. Cary Coglianese, Challenging the Rules: Litigation and Bargaining in the Administrative Process (1994) (unpublished Ph.D. dissertation University of Michigan) (on file with author); see also Kerwin supra note 16, at 182 - 84; Marissa Golden, Interest Groups in the Rulemaking Process, 8 J. PUB. ADMIN. RES. \& THEORY 245 (1998).

96 See Thomas C. Beierle, Resources for the Future, Discussing the Rules: EleCtroniC RULEMAKING AND DEMOCRATIC DELIBERATION (2003), available at http://www.rff.org/Documents/RFFDP-03-2.pdf; Brandon \& Carlitz supra note 3; Johnson supra note 3.

$97 \quad$ For example, Robert Hahn and Robert Litan have proposed that agencies provide consistent reporting of regulatory analysis results for this reason. See Robert W. Hahn \& Robert E. Litan, Recommendations for Improving Regulatory Accountability and Transparency, Testimony before the House Government Reform Committee, Subcommittee on Energy Policy, Natural Resources and Regulatory Affairs, at 10, (March 2, 2003) available at http://aei-brookings.org/admin/pdffiles/phpk0.pdf. 
Goal 2: Improve Policy Decisions. If information technologies make it easier for rule writers to retrieve and process information needed to develop sound regulatory policy, then e-rulemaking should presumably lead to better decisions. After all, making good regulatory decisions usually requires having extensive information about the underlying problem, its causes, and the predicted effects of different possible solutions. ${ }^{98}$ Information technology could make it easier for regulatory officials to analyze large volumes of data drawn from multiple sources.

With a better understanding of the underlying behavioral and technical conditions that affect regulatory problems and their solutions, regulators would be better positioned to draft rules that are more effective, as well as perhaps more cost-effective or efficient. Of course, even if information technology clearly makes regulatory decision makers better informed, the introduction of such technology is only worthwhile if regulators make decisions that draw upon and are consistent with the additional information they acquire. ${ }^{99}$ Moreover, the goal is for regulators to make decisions that are better than the ones that they would have made had they not had the benefit of the information technology. If a regulatory agency ends up writing the same kinds of rules it would have otherwise written before the introduction of some new type of information technology, then e-rulemaking will not have met the goal of improving policy decisions. ${ }^{100}$

As with the goal of democratic legitimacy, the goal of improving policy decisions can be characterized more concretely. In particular, designers and decision makers can distinguish between three main ways of improving regulatory policy. The first way is to consider the impact the regulation has in terms of solving the regulatory problem. ${ }^{101}$ The regulatory problem might be, for example, either health risks from air pollution or fatalities from automobile accidents. If the goal is just to increase the impacts -- or benefits -- of a rule, then e-rulemaking would meet this goal if it enabled agencies to craft regulations that decreased air pollution risks or reduced the number of crash-related fatalities, at least relative to rules crafted without the benefit of the relevant information technology.

A second way to improve regulatory policy is to improve its cost-effectiveness. ${ }^{102}$ In order to achieve benefits such as reduced air pollution or greater automobile safety, regulated firms incur costs, such as to install safety or pollution control devices. These costs should be taken into account, in addition to the benefits, when assessing the quality of a rule. If Rule A achieves the same level of benefits as Rule B, but the economic costs associated with complying with Rule A are less than the costs associated with Rule B, then Rule A is more cost-effective than Rule B. If technology better enables the regulator to analyze information about costs as well as benefits (assuming access to costs is even

98 See Aaron B. Wildavsky, Speaking Truth to Power: the Art and Craft of Policy Analysis, (1979); David L. Weimer \& Aidan Vining, Policy ANalysis: Concepts and Practice (1992).

99 See Cary Coglianese, Empirical Analysis and Administrative Law, 2002 U. ILL. L. ReV. 1111, $1122-23$ (2002).

$100 \quad I d$.

101 Lawrence B. Mohr, Impact Analysis for Program Evaluation (2D ED. 1995).

102 For the distinction between efficiency and cost-effectiveness, see Robert W. Hahn et al., Environmental Regulation in the 1990s: A Retrospective Analysis, 27 Harv. Envtl. L. Rev. 377, 377 n. 1 (2003). 
available to government), e-rulemaking might lead agencies to develop more costeffective rules.

In the same way, information technology might help regulators improve the efficiency of their rules, the third way policy improvement can be understood. ${ }^{103}$ Like the cost-effectiveness criterion, efficiency takes both benefits and costs into account. But unlike cost-effectiveness, which is all about achieving a given level of benefits for the lowest cost possible, efficiency asks whether the benefits outweigh the costs. ${ }^{104}$ In other words, even the most cost-effective regulation might, in some situations, impose costs that exceed the value of the benefits to be gained. In contrast, efficient policies will maximize positive net benefits, that is benefits minus costs. ${ }^{105}$

Other criteria, such as the distribution of costs and benefits of regulation across society, could also be used to measure the quality of rulemaking. ${ }^{106}$ Overall, the goal of improving regulatory policy through e-rulemaking could be expressed in metrics that include:

- Benefits to society, such as reductions in risks or other regulatory problems

- Costs to society, in terms of the compliance and opportunity costs associated with achieving the required regulatory benefits

- Comparisons of costs and benefits, either in terms of cost-effectiveness or efficiency

- Equity considerations related to the distribution of costs and benefits

Goal 3: Decrease Administrative Costs. Managing the rulemaking process can also be costly and at times burdensome to regulatory agencies. A third goal for erulemaking would be to decrease the administrative costs associated with rulemaking, that is, to lower the costs that government incurs in developing new rules. Information technology may allow agencies to carry out existing rulemaking responsibilities in less costly ways. For example, the Department of Transportation has reported saving more than a million dollars in storage costs each year from its investment in an online docket system. $^{107}$

Information technology may also help agency managers better coordinate rulemaking staff and other resources. For example, a docketing system that tracks each rule may provide information to managers about common procedural bottlenecks, perhaps suggesting areas where staffing levels should be adjusted in order to reduce delays. ${ }^{108}$

103 Efficiency can be conceived either as Pareto efficiency, which is achieved if no person is made worse and at least one person is made better, or as Kaldor-Hicks efficiency, which occurs if those who gain from a decision gain more in the aggregate than the losers lose. See RICHARD A. POSNER, ECONOMIC ANALYSIS OF LAW 12-13 (6 ${ }^{\text {th }}$ ed. 2003)

104 See generally Matther D. Adler \& ERIC A. Posner, Eds., Cost-Benefit Analysis: Legal, Economic, And Philosophical Perspectives (2000); Edward M. Gramlich, A Guide to BenefitCost ANALYsis (2d ed. 1997).

$105 \quad$ See Gramlich supra note 104.

106 See Arthur OKun, Equality And EfFiciency: The Big Tradeoff (1975).

107 See Neil Eisner, Presentation to John F. Kennedy School of Government Workshop on ERulemaking 76 (Jan. 21, 2003), at http://www.ksg.harvard.edu/cbg/Conferences/rpp_rulemaking/Eisner_ Presentation.pdf.

$108 \quad$ See Eisner supra note 107. 
Information systems may also be used to evaluate the performance of rulemaking staff, improve communication across the agency and with OMB, and allow enforcement offices to monitor new rules proactively and plan compliance strategies accordingly.

Finally, information technology may help administrators with the task of reviewing and responding to public comments. At present, agencies sometimes will delegate the task of analyzing public comments in major rulemakings to private contractors, some of whom will physically cut and paste hard copies of the comments in order to sort them into manageable categories. Information technology may provide superior and less costly methods of analyzing comments, identifying different issues and opinions expressed in them, and even perhaps providing automatic summaries of them. ${ }^{109}$

Possible metrics that reflect the broader goal of reducing administrative costs could include:

- Amount of time it takes to develop a rule, from initial consideration to final rule

- Number of staff members (or full-time equivalents) used

- Budgetary costs related to rulemaking

Goal 4: Increase Regulatory Compliance. A final goal of e-rulemaking could be to increase compliance with the rules agencies promulgate. Regulation is designed to achieve social goals by bringing the behavior of businesses and individuals into alignment with the law. To the extent that information technology can help increase compliance with rules, it can help in achieving the underlying social goals that the rules are intended to serve.

Of course, if those who are targeted by regulation do not know about or understand the rules that apply to them, compliance will be at best something that is hit or miss. Perhaps some actors will comply for reasons unrelated to the rules, but many undoubtedly will not. So the first step in increasing compliance will be to increase awareness and understanding of regulations. ${ }^{110}$ Compliance assistance systems may make it easier for businesses to identify rules that apply to them. For example, even though a small print shop may be unable to afford to hire an attorney, the owner or shop manager could more easily use a software package that asks a series of questions about the shop's operations and then provides information about what rules apply to the facility. ${ }^{11}$

In addition to knowing which rules apply, regulated entities also need to understand exactly what to do in order to comply with the rules. Unfortunately, the rules in the Code of Federal Regulations are not always clear nor easy for non-legal professionals to follow. The same kind of compliance assistance system that could help the small business identify rules to follow could also translate those rules into plain

$109 \quad$ See Brandon \& Carlitz supra note 3, at 1452.

110 Dorothy Thornton et al., General Deterrence and Corporate Environmental Behavior (Center for the Study of Law and Society Jurisprudence and Social Policy Program. JSP/Center for the Study of Law and Society Faculty Working Papers. Paper 16).

111 On compliance assistance and regulation generally, see Shawn Kerrigan \& Kincho H. Law, LogicBased Regulation Compliance Assistance, Submitted to the Ninth International Conference on Artificial Intelligence and Law (June 24-28, 2003, Edinburgh, Scotland, UK). 
English (or another language) and provide easy-to-follow information about what the facility needs to do to comply with the applicable regulations. ${ }^{112}$

The possible metrics for the goal of increasing compliance include:

- Level of knowledge of rule and what it requires with the regulated sector

- Extent of compliance with rule

Relationships and Tradeoffs Between Goals. Any consideration of the goals for e-rulemaking should first take into account whose goals they are. Different users will have different goals. For e-rulemaking, the users will be a highly diverse lot, including those who work within various agency offices, Congress, the White House, other agencies, regulated firms and trade associations, nongovernmental organizations, citizens, academic researchers, and professional organizations. Goals are likely to vary depending on who are the primary users of any new technology in the rulemaking process. Moreover, the users may have different goals from those who are funding new technologies or who otherwise oversee the users.

Designers and decision makers also need to recognize that some types of information technologies will be better suited for some goals rather than for others. Erulemaking is not a single strategy, but a general term that encompasses many different types of tools and procedures that rely upon information technology. Some tools will be better suited for achieving certain goals than others. For example, issuing rules in software format rather than as conventional text - the so-called TurboTax ${ }^{\circledR}$ approach to rulemaking -- might help with compliance, but it probably would not by itself directly improve the substance of the rules.

That said, many e-rulemaking efforts will likely have impacts on more than one goal, sometimes even posing tradeoffs across different goals. For instance, a TurboTax ${ }^{\circledR}$-type rule might help with compliance, but it could be more costly for the agency to produce. It might also raise concerns about legitimacy because, as one workshop participant noted, a software package may be less transparent and harder for the public or courts to scrutinize than a traditional text-based rule.

Another example of a tradeoff might be when information technologies increase the number of comments (a possible indicator of increased democratic legitimacy), but in doing so they also increase the administrative costs associated with rulemaking. ${ }^{113}$ More comments may correspond to more viewpoints, more concerns, and more conflicts or issues that need resolution, thus potentially making the rulemaking process take longer to complete. ${ }^{114}$ Even if information technology makes it easier to process the information contained in a larger volume of comments, this information could potentially make the decision calculus for the agency more complex or uncertain, especially if the information submitted is internally inconsistent. ${ }^{115}$ Quite plausibly a tradeoff exists between the

\footnotetext{
$112 \quad I d$.

113 For a related argument on how high-volume participation can compromise deliberation, see Jim Rossi, Participation Run Amok: The Costs of Mass Participation for Deliberative Agency Decisionmaking, 92 Nw. U. L. REV.173 (1997).

$114 \quad$ See Brandon \& Carlitz, supra note 3, at 1452; Beierle, supra note 96, at 14.

115 See James K. Hammitt, Can More Information Increase Uncertainty? 8 CHANCE (Summer 1995), at $15-17$.
} 
amount of time needed to issue a rule and the rule's quality (or the level of satisfaction with the rule, which may not necessarily equate with quality). ${ }^{116}$

Of course, the ideal situation would be to find information technologies that resolved tradeoffs or minimized them. Recognizing that such tradeoffs exist, though, will be the first step toward finding ways to overcome them. Furthermore, in many cases such tradeoffs will be irresolvable (at least in the near term), so systems designers and agency decision makers will need to make choices about priorities between the various goals for e-rulemaking.

\section{B. Technology Design Choices}

Key choices about information technology should be made in ways that advance e-rulemaking's main goals. Participants at the Regulatory Policy Program's e-rulemaking workshops highlighted a variety of design choices, such as those about flexibility, accuracy, security, and other characteristics or dimensions of IT systems. Making choices about these various dimensions will depend on the desired goals of e-rulemaking and the needs and capabilities of system users. Some of the design choices noted during the workshop included the following.

1. Degree of Uniformity. The performance of IT systems can be greatly enhanced when they rely on globally uniform lexicons, data structures, and training materials. Absent uniformity, systems need to be made adaptable to differences in terminology and needs across different rulemaking proceedings or different agencies. Some participants argued that uniformity across government is important, especially to help public users who work with multiple agencies. Also, uniform systems may better exploit economies of scale, though perhaps with the negative effect of decreasing the innovation that decentralized systems would foster. Others argued that non-uniform systems will be more quickly developed and more easily configured to new circumstances if they are designed to be adaptable to different user and agency needs, particularly the distinct uses of technical language found across different regulatory areas. Advocates of smaller, more modular systems believed systems designed to accommodate different needs could eventually "learn on their own" by adapting system ontologies or lexicons based on the texts that they process.

2. Degree of Complexity. Systems can be structured in complex ways that mirror the complexity of regulatory issues and processes, or they can be built on more simple models. The entry interface for initial users should be based on a simple model, with more complex presentations available for advanced users. Even where complexity of presentation cannot be avoided, information tools such as graphical maps showing linkages and tracking the paths have been explored can make the system interface more convenient for users to interact with and understand.

3. Use of Metadata. Metadata are descriptions of data. Systems could be designed to search the data themselves or to search by metadata instead (or sometimes to search by both).

116 On the distinction between satisfaction and quality, see Cary Coglianese, Is Satisfaction Success? Evaluating Public Participation in Regulatory Policy Making, in ROSEMARY O'LeARY AND LISA Bingham, eds., The Promise and Performance of Environmental Conflict Resolution 69(2003). 
4. Structure Definition. Who should define how systems are structured? Systems can be structured in a manner determined by the agency's upper management, or they can be structured by the users themselves and hence customized to different uses and needs.

5. Scalability. Systems can be designed for different numbers of users or different volumes of data. To what scale should e-rulemaking systems be designed? Or should systems be designed so that their scale can vary depending on users' needs?

6. Privacy. Privacy issues arise in a number of contexts. One involves the protection of confidential business information as it pertains to rulemaking, a matter related to security issues. Another privacy concern involves the treatment of public comments in on-line dockets. The Department of Transportation currently creates an online list of commentators by name, while the EPA does not. ${ }^{117}$ Should the identities of individuals or organizations filing comments be easily searchable in agency dockets? ${ }^{118}$

7. Security. Security typically is assured through access control, restricting who gains access to information contained on agency systems. But security could also be obtained through release control -- or filtering information as it leaves a system. One participant noted that release control will be more effective than access control, but it is probably also more costly.

8. Accuracy. Especially with respect to information retrieval systems, accuracy will be a key issue. How accurate do such systems need to be? Do systems need to be $100 \%$ accurate, as accurate as a human, or accurate to some other degree? Also, will it be more important to avoid false positives or false negatives? No matter how these questions are resolved, it will help increase trust in information systems if they are designed to report their results together with an indication of the confidence in them.

9. Human-Computer Interface. When designing IT systems to support government rulemaking, numerous design choices will arise about how to communicate information to users. This is a vast and complex issue, as there is a large variety of input devices and output displays. If rulemaking documents are to be accessible to the broadest possible audience, including those with disabilities, users with older technologies, or just the average person trying to wade through dense technical information, e-rulemaking will pose significant challenges in terms of human-computer interface and graphical design. ${ }^{119}$

10. Public Outreach. Agencies can obtain comments from self-selected commentators who take the time to contact the agency or they can seek out comments from the public, such as through randomly selected surveys. ${ }^{120}$ The current practice of opening up proposed rules for comment is reactive: the agency issues a notice and waits for the public to submit comments. The other approach, which may be made easier by information technology, is for the agency to be proactive and reach out by contacting individuals and soliciting their input. Furthermore, comments could be designed at varying levels of interaction between government and other commentators - ranging

117 Barbara H. Brandon, An Update on The E-Government Act and Electronic Rulemaking, 29 ADMIN. \& REG. L. NEWs, Fall 2003, at 7.

118 See Brandon \& Carlitz, supra note 3; Lubbers, supra note 79

119 For background on human-computer interface, see JOHN CARROLL, ED., HCI MODELS, THEORIES, AND FRAMEWORKS : TOWARD A MULTIDISCIPLINARY SCIENCE (2003).

120 See Peter M. Shane, Online Deliberation Tools and Electronic Rulemaking, Presentation to John F. Kennedy School of Government Workshop on E-Rulemaking (Jan. 21, 2003) at http://www.ksg.harvard.edu/cbg/Conferences/rpp_rulemaking/Shane_Deliberation_Tools.pdf 
from the typical one-shot submission of comments to on-line deliberations between commentators. Such deliberations could be either moderated or unmoderated. ${ }^{121}$

11. Structure of Public Input. A related choice is between open-ended versus structured comments from the public. An agency could structure input by providing a list of key issues from which commentators can check specific boxes reflecting their preferences. Garnering structured comments would probably make it easier to categorize and analyze them, which may make them more helpful to agency, but open-ended comments may fit better with the goal of democratic legitimacy. Of course, even if an agency did seek structured comments, the system could also be designed to allow commentators to override the structure and offer open-ended responses instead of, or in addition to, structured responses. ${ }^{122}$

12. System Costs. Different design choices will have different costs associated with them and agencies will need to make decisions about how much they would like to spend on the design and operation of information technology. Although this point may seem obvious, recognition of the financial implications of design choices raises the more general point that e-rulemaking must confront institutional challenges and constraints in addition to technological ones.

\section{Institutional Challenges and Constraints}

Undoubtedly e-rulemaking will present significant and interesting technological challenges in terms of semantic representation, human-computer interface, privacy and security, or the adaptability of systems. But workshop participants also recognized that to be successful e-rulemaking must also take into account a series of no less significant institutional challenges. Systems that agencies cannot afford, or that do not fit well the needs or practices of agency officials, will likely prove to be ineffective, no matter how technologically innovative they may be. Successful e-rulemaking efforts will therefore need to integrate both technological and institutional analysis, taking organizational needs and constraints explicitly into account in designing information systems. Workshop participants noted at least three specific institutional constraints or challenges that will likely influence the incorporation of information technologies into the rulemaking process.

The first major institutional challenge that workshop participants highlighted was the need for cooperation both within and across government agencies. Particularly with efforts to build uniform or government-wide platforms, coordination across agencies will be important but challenging. ${ }^{123}$ Getting different staffs, offices, and agencies to work together in designing a system generates transaction costs and may reveal that participants have different, perhaps even sometimes incompatible, preferences about the design and performance of systems. This kind of cooperation is often not easy to accomplish, even within the same agency. As a result, the implementation of e-

\footnotetext{
$121 \quad$ See Bierle, supra note 96.
}

122 See Group A, Presentation to John F. Kennedy School of Government Workshop on ERulemaking (Jan. 21, 2003), at http:/www.ksg.harvard.edu/cbg/Conferences/rpp_rulemaking/Liddy_Rapporteur.pdf.

123 See Eugene Bardach, Getting Agencies to Work Together: The Practice Anf TheOry of MANAGERIAL CRAFTSMANSHIP (1998). 
rulemaking may take longer if all systems need to be uniform and not merely compatible. Seeking uniformity may also affect the quality of information technology if cooperation is achieved by designing systems to the lowest common denominator.

The second institutional consideration participants noted was organizational inertia. E-rulemaking may necessitate what some participants called a cultural change within government agencies. Many agency personnel have been doing what they are doing for quite some time, without innovative forms of information technology. As a result, many of them may fail to see the advantages of e-rulemaking. Not only will training be essential when new systems are introduced, but so will be ongoing technical support and a management commitment to new technology. Participants predicted resistance to new systems and a risk of atrophy over time. For example, agency staff will have little incentive to favor systems that facilitate the submission of additional comments, since this will mean additional work for them and raise fears that opponents of a rulemaking could flood the agency with comments. Similarly, agency staff can be expected to oppose new docket management systems that allow agency managers to monitor staff performance more closely. Ultimately, leadership from the top will be important to the long-term sustainability of e-rulemaking, especially in order to keep information systems up to date. ${ }^{124}$ But even leadership will be a challenge since the appointees who head agencies turn over frequently and thus typically have a short term focus.

Workshop participants pointed to administrative law and existing rulemaking procedures as a final institutional constraint. ${ }^{125}$ At a minimum, information systems will need to be designed so that they comport with proper legal procedures. For example, security practices must be designed to meet existing legal standards for protecting confidential business information. ${ }^{126}$ This may require that software be designed to allow agency staff to redact portions of documents electronically before placing them in agency dockets. In addition, information systems will need to adapt to changes in legal procedures. If new procedural requirements are added to the rulemaking process, such as by adding steps or requiring new analysis, then information systems will need to be able to accommodate these changes.

Still more challenging is the question of whether law itself should change in light of the capabilities of new information technologies. ${ }^{127}$ For example, at the present time, many agencies document so-called ex parte conversations - i.e., conversations with outside interests - by drafting memoranda summarizing these conversations and submitting them to the rulemaking docket. Digital technologies would make it increasingly easy to record such ex parte communications digitally and then upload the

124 See Elaine Ciulla Kamarck \& Joseph S. Nye, DEMOCRACY.COM?: GOVernanCE IN A NETWORKED WORLD (1999).

125 See Lubbers, supra note 79

126 For examples of a few regulations applicable to the handling of confidential business information, see Department of Agriculture, Handling Information from a Private Business, 7 C.F.R. §1.12; Environmental Protection Agency, Confidentiality of Business Information, 40 C.F.R. Subpart B; and National Highway Traffic Safety Administration, Confidential Business Information, 49 C.F.R. Part 512.

127 See, e.g., James T. O'Reilly, Let's Abandon Regulatory Creationism: The Case for Access to Draft Agency Rules, 28 Admin. \& Reg. L. News 4 (2003). 
audio file to the on-line docket. ${ }^{128}$ We are living in an era where such "ultratransparency" to the governmental process is now possible. Is it also desirable?

A further question about the role of agency expertise can be raised by the ease with which agencies will be able to solicit public comment. Much of administrative law is still based on deference to agency expertise, and agencies are charged with carrying out their congressional mandates in ways that comport with their expert judgments about what best serves the public interest. But when information technology now makes it possible for hundreds of thousands of citizens to submit comments on a proposed rule, it may be time to reexamine the role of democratic responsiveness in rulemaking. ${ }^{129}$ Perhaps courts will come to view legislative policy making by agencies as more like legislative policy making by the Congress. If nothing else, perhaps judges will expect agencies to give stronger justifications for decisions that run contrary to overwhelming expressions of public preferences.

E-rulemaking raises important questions about the future of administrative law. Moving forward to craft effective e-rulemaking will require careful consideration of these and other institutional issues, in addition to addressing important issues of technological design. Although choices about system design should be guided by decision makers' goals for e-rulemaking, achieving these goals will also require that designers and decision makers work within or overcome a series of constraints. Some of these constraints will undoubtedly be technological ones, but participants suggested that the technological constraints may prove easier to overcome than the institutional ones. As a result, effective change in this area will be enhanced by a robust agenda for research on both technology and institutions, as well as on the relationships between the two.

\section{Directions for Future Research}

In the short term, agencies have available to them a variety of technologies that stand ready to use in rulemaking, as soon as institutional barriers to their widespread adoption can be overcome. These near term technologies will build upon the existing rulemaking process, providing greater access and transparency to the work of regulatory agencies. But in the medium to longer terms, e-rulemaking has the potential to go well beyond just digitizing the current process. With the appropriate institutional adoption of innovations in technology, some aspects of the rulemaking process could be improved significantly, if not redesigned altogether. Some workshop participants predicted revolutionary changes over the long term with the development of new technologies. ${ }^{130}$

In order to tap e-rulemaking's fullest possible potential, research will be needed from across a variety of disciplines, including computer sciences, law, economics,

$128 \quad$ See Coglianese, supra note 83.

129 For a discussion of this point, which argues in favor of the existing emphasis on agency expertise over democratic responsiveness, see Randolph J. May, Under Pressure: Campaign-style Tactics are the Wrong Way to Influence Agency Decisions, LEGAL TIMES (July 7, 2003).

130 One administrative law scholar has even predicted that information technology will "change everything" when it comes to administrative rulemaking. Johnson, supra note 3, at 277 ("The Internet could be used to revolutionize each step of the process that agencies must follow under the APA by supplementing, rather than replacing, those processes"). 
political science, and organizational theory. This final Part offers guidance for crossdisciplinary research aimed at making medium- and long-term impacts on e-rulemaking. It presents a policy analytic framework for organizing future research, highlights the different functional aspects of rulemaking deserving of research, and outlines a series of research questions raised by workshop participants. With coordinated input from both informational and institutional disciplines, researchers will be able to contribute to the development of more effective technological solutions and better assess the impact that digital tools have on agency rulemaking.

\section{A. Policy Analysis Framework}

The ultimate test for e-rulemaking will be whether it improves either the substance or process of rulemaking (or both). Since information technology offers potential solutions to problems with rulemaking, research will be needed to determine the extent to which information technology actually mitigates these problems or advances the goals of those who implement it. Previous sections of this article have highlighted some of the problems with rulemaking and have articulated different goals for e-rulemaking. ${ }^{131}$ In this section, rulemaking problems and e-rulemaking solutions are organized within the framework of policy analysis or evaluation. This framework is intended to illuminate the different roles for institutional and informational research in finding ways to improve government rulemaking.

The conventional approach to policy analysis begins by specifying and studying problems. ${ }^{132}$ With respect to rulemaking, as noted in Part I of this article, observers have variously defined the problems as ones of inefficiency, delays, lack of democratic responsiveness, or incomplete compliance. ${ }^{133}$ Merely stating that a problem exists, however, is but the first step in policy research. The researcher next defines the problem as precisely as possible, measures the extent of the problem, and identifies trends in the problem. $^{134}$ Is the problem getting worse or better? Most importantly, the researcher examines the causes of the problem because knowing the underlying causes will help in identifying solutions.

By understanding the problem better, the policy researcher is able to specify criteria by which alternative solutions to the problem can be assessed. ${ }^{135}$ Some of these criteria will relate directly to the problem, such as by selecting metrics to determine how well a particular solution reduces the problem. ${ }^{136}$ Other criteria will relate to constraints on decision makers or organizations. ${ }^{137}$ In the rulemaking context, for example, solutions that might improve regulatory compliance will also impose administrative costs on

\footnotetext{
$131 \quad$ See supra Part II.A.

132 See, e.g., EDITH StOKEy \& Richard ZECKhauser, A PRIMER FOR Policy ANALYSIS (1978); David L. Weimer \& Aidan R. Vining, Policy Analysis: Concepts And Practice (3rd ed. 1998).

$133 \quad$ See supra notes 37-39 and accompanying text.

$134 \quad$ See Stokey \& Zeckhauser, supra note 132; Weimer \& Vining, supra note 132; EUGENE BARDACH, A Practical Guide for Policy Analysis: The Eightfold Path to More Effective Problem SOLVING (2nd ed. 2000).

$135 \quad$ See generally Stokey \& Zeckhauser, supra note 132; Weimer \& Vining, supra note 132; Bardach, supra note 134.

136 For examples of some possible criteria for e-rulemaking, see the metrics highlighted in Part II.A.

$137 \quad$ See generally Stokey \& Zeckhauser, supra note 132.
} 
agencies. Decision makers need to reduce the problem of noncompliance (or any other problem) within their financial constraints. Researchers should therefore assess alternative solutions along a number of dimensions, such as the impact on the problem as well as on factors such as administrative costs or legal feasibility. In selecting criteria, erulemaking researchers will be able to draw on goals and metrics such as those discussed earlier in this article.

After analyzing the problem and selecting criteria, the next step is to identify alternative solutions. ${ }^{138}$ Policy research compares alternatives, of which at least two always exist: (1) the status quo and (2) something that would change the status quo. ${ }^{139}$ No matter how many alternative solutions are considered, the status quo (or the "do nothing" option) is always included as the benchmark against which the alternatives are compared. Often there will be several alternative ways of changing the status quo that the researcher will want to consider. E-rulemaking encompasses a broad range of applications of information technology, each of which can have different design choices embedded within them. ${ }^{140}$ Each relevant type and design of information technology can be considered as a separate solution.

The analysis of the solutions consists of assessing each of the alternative solutions against all of the relevant criteria. How well do each of them solve the problem and avoid the constraints? If solutions have yet to be implemented, this analysis becomes prospective and must be based on forecasts or inferences from other comparable settings. If solutions have been implemented, then the analysis can consist of empirical study of their effects, comparing each of these results with the status quo or with the effects of other alternatives. ${ }^{141}$

On the basis of the analysis, a recommendation or decision can be made whether to implement or continue implementing the solution. In many cases, there will be tradeoffs to be made across criteria. In other words, some solutions may solve one problem well, but create new problems of their own or may cost more than other solutions. Choices will still need to be made, but they will be choices informed by a clearer understanding of the impacts of different options along the relevant criteria. ${ }^{142}$

Of course, the purpose of this overview of policy analysis is not to suggest that all research on e-rulemaking ought to be approached as policy analytic research. Rather, it is to provide an overarching framework for integrating the contributions of various disciplines -- computer sciences, social sciences, and the law -- in the advancement of erulemaking. Research from each discipline contributes in different ways to different parts of the policy analysis framework.

For example, social scientists seek to understand organizational and individual behavior in the rulemaking context. ${ }^{143}$ Their research on the rulemaking process provides

\footnotetext{
$138 \quad$ See Stokey \& Zeckhauser, supra note 132; Weimer \& Vining, supra note 132; Bardach, supra note 132 .

139 See Coglianese, supra note 98, at 1116 (discussing the status quo as a counterfactual).

$140 \quad$ See supra Part II.B.

141 Coglianese, supra note 99, at 1114-19.

$142 \quad$ See Stokey \& Zeckhauser, supra note 132; Weimer \& Vining, supra note 132; Bardach, supra note 134.

143 See, e.g., Scott R. Furlong, Interest Group Influence on Rulemaking, 29 ADMIN. \& SoC. 213 (1997); Marissa Martino Golden, What Motivates Bureaucrats: Politics and Administration DURING THE REAGAN YEARS (2000).
} 
a better basis for understanding problems and their causes. It also provides a baseline understanding of the status quo.

In contrast, the information sciences are particularly useful in identifying possible solutions. The innovative technologies developed by information scientists make up the alternative solutions that merit assessment for effectiveness.

Social science research will inform the work of information scientists in vital ways because information scientists need to understand the underlying structure of information and decision making in the rulemaking process. By identifying the causes of slow or inefficient decision making, social science research contributes insights that will enable information scientists to design systems that can address these causes and better meet users' needs.

In addition to the contributions made by the social and computer sciences, legal research will contribute to a better understanding of the constraints under which new technologies must operate. Administrative law scholars can also identify legal innovations and procedural changes that may complement or facilitate the application of innovations in information technology. ${ }^{144}$ These legal changes will themselves constitute alternative solutions meriting their own evaluation.

Finally, all disciplines can contribute research on the impacts of new technologies on the rulemaking process. Research that measures the effects of e-rulemaking will be relevant not only to decision makers but also to researchers from across the disciplines. Information scientists will want to know if their solutions have been effective and will benefit from evaluation results in order to refine technologies or search for new solutions. Social scientists and administrative law scholars will learn how information technology affects behaviors and outcomes in the rulemaking process.

Research from all disciplines will help in putting together the pieces of the policy analytic puzzle. Should new technologies be applied to rulemaking? Which ones? How should they be designed? What are the appropriate criteria or metrics for evaluating the impact of e-rulemaking? As indicated, answering these policy questions will require coordinated efforts across computer sciences, social sciences, and law.

\section{B. Functional Aspects of Rulemaking}

E-rulemaking research can benefit not only from an analytic framework but also from a functional perspective on rulemaking. Such a perspective considers the tasks that agency staff and other users undertake in developing and implementing rules.

A functional perspective differs in some ways from the perspective that social scientists and administrative law scholars typically offer. The typical perspective portrays rulemaking in a procedural manner, as a series of legal steps or hurdles that must be cleared. ${ }^{145}$ While e-rulemaking researchers do need to appreciate the procedural steps of rulemaking, this is not the only way to conceptualize the rulemaking process. A functional account of rulemaking emphasizes tasks instead of procedures. These tasks are ones that agency staff and other users must perform at a particular stage or at several stages of the rulemaking process. Many workshop participants characterized future research needs around different functional aspects of rulemaking. 
Some of these functional aspects are closely related to a particular procedural stage in rulemaking, while others cut across more than one stage. The tasks that workshop participants highlighted and thought were most likely to benefit from advanced information technology include the following.

- Gathering information. In order understand the extent of regulatory problems and analyze different solutions, agency staff must gather large quantities of information in the form of internal or external studies and analyses of available data. Relevant technologies include information retrieval, data and text mining, information extraction, summarization, and semantic analysis.

- Securing public input. Public input is another major source of information for regulatory decision makers, so agencies need to capture and analyze this input. Information technologies that facilitate digital deliberation will be relevant, as will be text classification and summarization technologies.

- Drafting rules. The process of writing a rule can be laborious, especially if it contain many parts or addresses complex problems. In addition, writing a rule often involves input from a number of staff members from different professional backgrounds (e.g., lawyers, engineers, economists, and enforcement staff). Stylechecking software, templates, and collaborative drafting tools are among the IT tools relevant to this task.

- Sharing information. An important part of rulemaking is sharing information with the public and with others in different parts of the government. Digital libraries, information retrieval, and question and answering systems are possible tools for sharing information.

- Securing compliance. One of the major tasks of any regulatory agency is ensuring that regulated actors come into compliance. Regulatory enforcement has traditionally served this role, but information technology may be able to help too. Relevant technologies could include regulatory conformance software or remote sensing technologies.

- Managing rulemaking. Managers within regulatory agencies need to make strategic choices about which rules to develop and how to allocate agency resources toward rulemaking. Relevant technologies could include systems that track the development of rules from inception through enforcement, as well as systems that can be used to set priorities and make budgetary decisions.

For the most part, the functional aspects of developing regulation have remained understudied. In contrast with myriad social science studies of members of Congress or even the Supreme Court, the available research on the job of a rule-writer in an administrative agency is remarkably thin. More research will therefore be useful for uncovering the specific challenges regulatory officials face in addressing each of these tasks. Another important area for research will be to determine whether variation exists 
in these tasks. It seems likely that the functional tasks of rulemaking will differ for different types of rules. If nothing more, the relative difficulty of these tasks seems likely to vary from rule to rule. Assuming this variation correlates with other identifiable features of rulemaking, it should be possible to design systems that offer different features designed to take such differences in tasks into account.

From the standpoint of evaluation, each different task can be viewed as a type of a problem, for each is a problem that the staff responsible for dealing with the task must solve. Correspondingly, the different types or designs of relevant information technology can be considered alternative solutions to these problems. Research organized around the functional aspects of rulemaking can assess how well different technological solutions impact the completion of the relevant task along various criteria, such as timeliness, expense, and effectiveness.

\section{Research Directions in E-Rulemaking}

Having recognized that research should assess the actual impacts of e-rulemaking on problems and functions, participants in the Regulatory Policy Program's workshops articulated a broad range of specific questions that they believed future research should address. The workshop dialogues covered a wide-ranging but interconnected set of research issues. For purposes of presentation, the ideas for future research that emerged can be organized into four main categories: (1) developments in information technology, (2) agency management of rulemaking, (3) public involvement in the rulemaking process, and (4) regulatory compliance.

1. Developments in Information Technology. E-rulemaking raises a series of challenges for research in the information sciences. ${ }^{146}$ The long-term potential for erulemaking will depend on adapting existing technologies to the rulemaking process as well as on making more fundamental progress in areas such as modeling, natural language processing, and human-computer interface. Some specific research questions directed at developing new IT applications include:

- How should IT tools be designed to perform automated cross-indexing and linking to related rules, docket records, and other relevant documents?

- How should rulemaking systems be designed to be clear and easy-to-use for a variety of users, from agency specialists to ordinary citizens?

- What structures and system designs will best facilitate clear and effective communication of the complex policy and procedural issues that characterize rulemaking?

- How can agencies structure technologies for public input that will encourage more members of the public to participate more meaningfully in the rulemaking process? 
- What kinds of technologies can be used for question-and-answer exchanges with the public? Can the technologies used by large companies to answer on-line user questions help agencies provide focused assistance to members of the public?

- How can IT tools be designed to help agency staff process and analyze commentary and dialogue from the public? Can systems be designed to categorize and summarize comments and generate responses to them?

- What technologies can best support interactive dialogue between the public and agency staff?

- How can general simulation and modeling packages - such as ones designed to assist with economic analysis - be constructed so they are useful to different regulatory agencies or for a variety of regulatory issues?

- How can software be designed to perform automated checking of rule documents for internal and external consistency?

2. Agency management of rulemaking. Information technology can help public managers improve their agencies' handling of rulemaking, but it may also create new management challenges of its own. ${ }^{147}$ The application of new information technologies to the rulemaking process generates a series of research questions for those interested in public management.

- What effects do information technologies have on agencies' ability to gather more or better information required for writing the rule? Does it enable rule-writers to conduct analyses or perform functions more quickly or with greater quality?

- What degree of flexibility is needed in IT systems that support rulemaking? Will structured systems help streamline the production process for new rules or will it create more work to adapt structured systems to meet contingencies related to each rule?

- How do agency staff members perceive the benefits and costs of information technologies in the rulemaking process?

- How does information technology affect the decision making within regulatory agencies? Does it change the relative influence that various professional staffs have inside an agency? For example, could lawyers lose influence over technical staff if IT systems made it easier for non-lawyers to draft rules?

- What kinds of changes, if any, does e-rulemaking bring to the relationships between regulatory agencies and other governmental actors, such as staff in Congress or the OMB?

147 For a discussion of management challenges with the introduction of IT into other aspects of government, see Fountain, supra note 10. 
- What aspects of the organizational culture within agencies are relevant to erulemaking? How can agencies make the organizational changes that might be needed in order to secure the full benefits of e-rulemaking?

3. Public involvement with rulemaking. E-rulemaking can affect both the internal management of regulatory agencies and the interaction between agencies and the public. Indeed, the management of public input is itself an important part of the strategic management of regulatory agencies, if for no reason other than that the rulemaking process is generally transparent to the public and involves extensive participation by outside organizations. ${ }^{148}$ Research on how information technology affects public participation will be of interest to those who study both public management and democratic politics. Some of the more important questions for research will include:

- Does public awareness of the rulemaking process increase after the introduction of new IT tools? Is this awareness increased more for some segments of the public than others?

- Does IT increase the number of comments submitted on proposed rules? Does it change who comments? Does it change the nature of the discourse?

- How does the public respond to different types of communication and deliberative technologies? How do different means of obtaining public input - email, videoconferencing, chatroom - perform according to different metrics?

- What does greater access of information do to media coverage? Does it make it less or more relevant? Does it increase coverage of regulatory issues? Does IT change the role for other information brokers (e.g., lawyers, trade associations) in the rulemaking process?

- Do comments have a different impact on agency decision making when agencies uses information retrieval software to analyze comments than when they use staff or consultants to analyze them?

- How do people "feel" after participating via these different means? Do they feel differently about email than a written comment, or about a videoconference than an in-person hearing?

- Does e-rulemaking affect the public's sense of legitimacy of regulations? Does it reduce conflict or decrease the incidence of litigation?

4. Regulatory compliance. The final set of research questions participants raised concern the role of information technology in promoting regulatory compliance. The point of making rules, after all, is to have them change the behavior of those they

148 See Mark H. Moore, Creating Public Value: Strategic Management in Government (1995). 
regulate. Research can be directed toward finding ways for information technology to promote regulatory compliance as well as determining what impacts information technologies have on the behavior of government enforcement staff and regulated firms. ${ }^{149}$ Some of the pertinent research questions include:

- How well can compliance assistance systems process users' descriptions of their situations and then identify all the relevant rules for users? Can effective systems be designed to help firms identify their own compliance and non-compliance with rules?

- What are the most effective ways to communicate regulatory requirements in compliance assistance software?

- How can systems best display or explain compliance to users, especially with respect to regulatory issues that possess so-called "gray areas?"

- How should compliance systems take enforcement discretion into account?

- What role can information technology and data acquisition play in improving evaluations of regulations? Can remote sensing technologies, for example, be used to link changes in underlying conditions with regulatory changes?

- How can systems be designed to process data on regulatory compliance in ways that will prove helpful for agency staff when revising old rules or creating new ones?

\section{Conclusion}

Through the rulemaking process, government agencies set standards that affect every major aspect of economic and social life in the United States. The volume and impact of government regulations have grown significantly over the past half century, making rulemaking one of the most important vehicles for government policymaking today. ${ }^{150}$ As a result, any proposal that promises to improve the rulemaking process by making it more efficient, less burdensome, or more accountable merits careful attention by both regulatory officials and policy researchers. E-rulemaking is one such proposal.

The term e-rulemaking actually encompasses a broad range of applications of information technology to the rulemaking process. While some agencies are beginning to make rulemaking documents available on the Internet, information technology could play a still more significant role. As participants in the Regulatory Policy Program's erulemaking workshops suggested, the potential for using IT in the rulemaking process is considerable. Agencies may be able to use new technologies to communicate more 
effectively with the public, conduct more informed regulatory analyses, and implement rules more quickly and efficiently.

While digital technologies offer better ways for agencies to complete existing tasks, they also may lead to a significant redefinition of the existing tasks and processes of rulemaking. For example, information technology may make it possible for agencies to be much more systematic about generating widespread public deliberation over proposed rules, perhaps enabling rulemaking in the future to be driven more by public preferences than by expert judgments. ${ }^{151}$ Whatever the merits of this or any other institutional change, it is clear that maximizing e-rulemaking's potential will depend on creating a good fit between information technologies and regulatory institutions.

Research from across the information and social sciences will therefore have much to offer to the development of e-rulemaking. Researchers working across disciplines can help design information systems that better meet the institutional routines and requirements of the rulemaking process. They can also evaluate the impacts of information technology on regulatory outcomes and behaviors. ${ }^{152}$ The effective use of information technology promises to advance important goals, such as improving regulatory decisions, enhancing democratic legitimacy, decreasing administrative burdens, and increasing regulatory compliance. But careful research will be needed in order to assess whether specific applications of technology actually advance these goals.

This article has identified numerous ways that information technology can be used to try to solve some of the problems associated with rulemaking. It has also highlighted key avenues for future research on e-rulemaking. Through coordinated efforts over the next decade, researchers should be able to answer many of the significant questions posed in this article and help bring about the development of more effective IT applications for rulemaking. The e-rulemaking efforts made so far by OMB and a core group of leading regulatory agencies represent important first steps, ${ }^{153}$ but sustained cooperation between these regulatory agencies and the research community will be essential to take e-rulemaking into its next generation.

$151 \quad$ See supra notes 90-97 and accompanying text.

$152 \quad$ See Coglianese, supra note 83.

153 See supra notes 43-66 and accompanying text. 


\title{
Appendix A
}

\author{
Information Technology and Rulemaking \\ Carnegie Endowment for International Peace \\ Washington, DC
}

March 26, 2002

Participants

Stanton D. Anderson

Special Assistant to the Director

Office of Information Technology and

E-Government

Office of Management and Budget

Steven J. Balla

Associate Professor

Department of Political Science and

Elliott School of International Affairs

George Washington University

Deborah Ben-David

General Counsel for Fisheries

National Oceanic and Atmospheric

Administration

U.S. Department of Commerce

Thomas C. Beierle

Fellow, Risk, Resource, and Environmental

Management

Resources for the Future

Barbara Brandon

Policy Analyst

Information Renaissance

Lawrence E. Brandt

Director

Digital Government Research Program

National Science Foundation
Tess Butler

U.S. Department of Agriculture

Grain Inspection, Packers, and Stockyards

Administration

Jamie Callan

Associate Professor

School of Computer Science (LTI) and

Heinz School of Public Policy and

Management

Carnegie Mellon University

Bob Carlitz

Executive Director

Information Renaissance

Cary Coglianese

Associate Professor of Public Policy

Chair, Regulatory Policy Program

Center for Business and Government

John F. Kennedy School of Government

Harvard University

Tricia Choe

Attorney Advisor

Department of Commerce

Daniel Cohen

Chief Counsel for Regulation

Office of the General Counsel

U.S. Department of Commerce 
Constance Downs

Administrative Assistant Director

Office of Environmental Information

U.S. Environmental Protection Agency

Neil Eisner

Office of General Counsel

U.S. Department of Transportation

Valerie Gregg

Program Manager

Digital Government Research Program

National Science Foundation

Davis A. Hays

Senior Fisheries Manager

National Marine Fisheries Service

National Oceanic and Atmospheric

Administration

Jim Hemphill

Office of the Federal Register

National Archives and Records

Administration

Deirdre Holder

U.S. Department of Agriculture

Grain Inspection, Packers, and Stockyards

Administration

Richard Kelly

U.S. Department of Agriculture

Animal and Plant Health Inspection

Service

Regulatory Analysis and Development

Ron Kelly

Executive Director

Regulatory Information Service Center

General Services Administration

Kincho Law

Professor of Civil and Environmental

Engineering

Stanford University
Jeffrey S. Lubbers

Fellow in Law and Government

Washington College of Law

American University

Gary Marchionini

Cary C. Boshamer Professor

School of Information and Library Science

University of North Carolina

Frances D. McDonald

Managing Editor

Office of the Federal Register

National Archives and Records

Administration

Oscar Morales

Director, Collection Strategies Division

Office of Information Collection

Office of Environmental Information

U.S. Environmental Protection Agency

Raymond A. Mosley

Director of the Federal Register

National Archives and Records

Administration

Jennifer Nash

Director, Regulatory Policy Program

John F. Kennedy School of Government Harvard University

Todd Olmstead

Research Fellow

Regulatory Policy Program

John F. Kennedy School of Government

Harvard University

Dawn Roddy

Lead Program Analyst

U.S. Environmental Protection Agency 
David Rostker

Policy Analyst, Office of Information and

Regulatory Affairs

Office of Management and Budget

James W. Sargent

Special Assistant to the Chief Information

Officer

NOAA Fisheries

Stuart Shulman

Assistant Professor

Environmental Science and Policy Program

Drake University

Geoff Steele

Program Manager

Regulatory Public Access System

Records, FOIA, and Privacy Branch

U.S. Environmental Protection Agency

Susan Stendebach

Program Manager

Digital Government Research Program

National Science Foundation

Michael White

Director of Legal Affairs and Policy

Office of the Federal Register

National Archives and Records

Administration 


\title{
Appendix B
}

\author{
E-Rulemaking: \\ New Directions for Technology and Regulation
}

January 21-22, 2003

John F. Kennedy School of Government

Harvard University

Participants

Micah Altman

Director, Virtual Data Center Project

Harvard-MIT Data Center

Harvard University

Steven J. Balla

Associate Professor

Department of Political Science and

Elliott School of International Affairs

George Washington University

Barbara Brandon

Reference Librarian

University of Miami Law School

Lawrence E. Brandt

Program Director

Digital Government Research Program

National Science Foundation

Jamie Callan

Associate Professor

School of Computer Science and

Heinz School of Public Policy and

Management

Carnegie Mellon University

Claire Cardie

Associate Professor

Department of Computer Science

Cornell University
Bob Carlitz

Executive Director

Information Renaissance

Cary Coglianese

Associate Professor of Public Policy

Chair, Regulatory Policy Program

John F. Kennedy School of Government

Harvard University

Curtis Copeland

Assistant Director

U.S. General Accounting Office

Neil Eisner

Office of General Counsel

U.S. Department of Transportation

Jose A. B. Fortes

Professor and BellSouth Eminent Scholar

Department of Electrical and Computer

Engineering

University of Florida

Jane Fountain

Associate Professor

Director, National Center for Digital

Government

John F. Kennedy School of Government

Harvard University 
Edward A. Fox

Professor

Department of Computer Science

Virginia Tech

Valerie Gregg

Program Manager

Digital Government Research Program

National Science Foundation

Davis A. Hays

Senior Fisheries Manager

National Oceanic and Atmospheric

Administration

U.S. Department of Commerce

Eduard Hovy

Deputy Division Director

Information Sciences Institute

University of Southern California

Roger Hurwitz

Research Scientist

The Artificial Intelligence Laboratory

Massachusetts Institute of Technology

Elena Kagan

Professor of Law

Harvard Law School

Neil Kerwin

Provost and Professor of Public

Administration

American University

Jay P. Kesan

Associate Professor

University of Illinois College of Law

Paul Lapsley

Director, Regulatory Management

U.S. Environmental Protection Agency
Kincho Law

Professor of Civil and Environmental

Engineering

Stanford University

David Lazer

Associate Professor of Public Policy

Associate Director, National Center for

Digital Government

John F. Kennedy School of Government

Harvard University

Elizabeth D. Liddy

Director of the Center for Natural

Language Processing

Syracuse University

Oscar Morales

Project Director, E-Rulemaking Initiative

Office of Environmental Information

U.S. Environmental Protection Agency

Jennifer Nash

Director, Regulatory Policy Program

John F. Kennedy School of Government

Harvard University

Beth Noveck

Associate Professor of Law

New York Law School

Rick Otis

Deputy Assistant Administrator

Office of Environmental Information

Environmental Protection Agency

Todd Rakoff

Byrne Professor of Administrative Law

Dean of the J.D. Program

Harvard Law School 
David Rostker

Policy Analyst, Office of Information and

Regulatory Affairs

Office of Management and Budget

Colin Rule

Director

The Online Public Disputes Project

Peter Shane

Distinguished Service Professor of Law

and Public Policy

Director, Institute for the Study of

Information Technology and Society

H.J. Heinz III School of Public Policy and

Management

Carnegie Mellon University

Stuart Shulman

Assistant Professor of Environmental

Science and Policy

Drake University

Sue Stendebach

Program Manager

Digital Government Research Program

National Science Foundation

Peter L. Strauss

Betts Professor of Law

Columbia University Law School

Michael White

Director of Legal Affairs and Policy

Office of the Federal Register

National Archives and Records

Administration

Gio Wiederhold

Professor Emeritus

Computer Science, Electrical Engineering, and Medicine

Stanford University
Steve Zavestoski

Assistant Professor

Department of Sociology

University of San Francisco 